\title{
Key Targets for Improving Algal Biofuel Production
}

\author{
Gareth Griffiths ${ }^{1, *}$, Abul Kalam Hossain ${ }^{1} \mathbb{D}$, Vikas Sharma ${ }^{1}$ and Ganesh Duraisamy ${ }^{2}$ \\ 1 Energy and Bioproducts Research Institute (EBRI), College of Engineering and Physical Sciences, \\ Aston University, Birmingham B4 7ET, UK; a.k.hossain@aston.ac.uk (A.K.H.); v.sharma10@aston.ac.uk (V.S.) \\ 2 Internal Combustion Engineering Division, Department of Mechanical Engineering, Anna University, \\ Chennai 600-025, India; ganvas12@annauniv.edu \\ * Correspondence: g.griffiths@aston.ac.uk; Tel.: +44-121-204-3415
}

Citation: Griffiths, G.; Hossain, A.K.;

Sharma, V.; Duraisamy, G. Key

Targets for Improving Algal Biofuel Production. Clean Technol. 2021, 3,

711-742. https://doi.org/10.3390/ cleantechnol3040043

Academic Editor: Sarat

Chandra Togarcheti

Received: 22 July 2021

Accepted: 23 September 2021

Published: 9 October 2021

Publisher's Note: MDPI stays neutral with regard to jurisdictional claims in published maps and institutional affiliations.

\begin{abstract}
A number of technological challenges need to be overcome if algae are to be utilized for commercial fuel production. Current economic assessment is largely based on laboratory scale up or commercial systems geared to the production of high value products, since no industrial scale plant exits that are dedicated to algal biofuel. For macroalgae ('seaweeds'), the most promising processes are anaerobic digestion for biomethane production and fermentation for bioethanol, the latter with levels exceeding those from sugar cane. Currently, both processes could be enhanced by increasing the rate of degradation of the complex polysaccharide cell walls to generate fermentable sugars using specifically tailored hydrolytic enzymes. For microalgal biofuel production, open raceway ponds are more cost-effective than photobioreactors, with $\mathrm{CO}_{2}$ and harvesting/dewatering costs estimated to be $\sim 50 \%$ and up to $15 \%$ of total costs, respectively. These costs need to be reduced by an order of magnitude if algal biodiesel is to compete with petroleum. Improved economics could be achieved by using a low-cost water supply supplemented with high glucose and nutrients from food grade industrial wastewater and using more efficient flocculation methods and $\mathrm{CO}_{2}$ from power plants. Solar radiation of not $<3000 \mathrm{~h} \cdot \mathrm{yr}^{-1}$ favours production sites $30^{\circ}$ north or south of the equator and should use marginal land with flat topography near oceans. Possible geographical sites are discussed. In terms of biomass conversion, advances in wet technologies such as hydrothermal liquefaction, anaerobic digestion, and transesterification for algal biodiesel are presented and how these can be integrated into a biorefinery are discussed.
\end{abstract}

Keywords: biofuels; microalgae; macroalgae; biomethane; bioethanol; biohydrogen; biodiesel; bio-oil; hydrothermal liquefaction; anaerobic digestion

\section{Introduction}

Fuel must be affordable and will always be compared to petroleum-based fuel, both in terms of cost and in overall performance. Whilst it is currently economical to produce algae for food or high value products, there are a number of cost constraints which limit their present use as a fuel feedstock, such as key issues around nutrient supply, harvesting, and dewatering [1,2]. Given the wide range of variation in the chemical composition of algae, the potential exits to generate a diversity of fuel types from them such as bioethanol [3], biohydrogen [4], biomethane [5], bio-oil [6], and biodiesel [7]. All algae share one common feature though, and that is a high water content. This is generally an undesirable component to have in any fuel type and therefore technologies that rely on a low water content, such as fast pyrolysis (FP) used to generate bio-oils, for example, become economically challenging because of the cost implications involved in drying the material. Fast pyrolysis, although suitable for use with relatively dry biomass (moisture content $<5 \%$ ) such as lignocellulosic material [8], is generally unsuitable for wet algae both in terms of the energy required and the products that are generated which cause fouling of the reactors. Out of practical necessity, therefore, this limits the choice for fuel production to wet technologies such as fermentation, hydrothermal liquefaction, or biodiesel generation from solvent extracted 
oils. In this review we will consider the types of algae that could be used, i.e., large 'seaweed-type' and microscopic single cell algae, the cost implications in growing and harvesting, and the current state of the art in biomass to fuel conversion technologies.

\section{Algal Taxonomy}

There is considerable debate as to the actual number of algal species that exist with conservative estimates of $\sim 250,000$ species, with others putting this figure likely closer to 1.5 million species [9]. Certainly, the advancement in molecular genetics is likely to unveil more complexities and perhaps add further numbers to this total [10]. Algal taxonomy is a key discipline in phycology and is critical for algal genetics, physiology, ecology, applied phycology, and particularly bio-assessment. In many ways, the taxonomy of the algae is in a state of flux and is being driven by rapid molecular techniques that have become available in recent years. The classification below into nine divisions (phyla) incorporate the older classifications into Red algae, Green algae, and Brown algae, since the latter are grouped under Heterokontophyta and include other major groups such as the Diatoms (with a silica based 'shell' and Golden algae or Chrysophyta) (Table 1) [11,12]. Cyanophyta are prokaryotic (relatively simple internal differentiation) and hence considered as photosynthetic bacteria rather than 'true' algae that are eukaryotic containing complex inner membrane compartments. In terms of human usage, the main algal groups are the Chlorophyta, Rhodophyta, and Phaephyceae [13].

Table 1. Classification overview of algae. Constructed from [11,12].

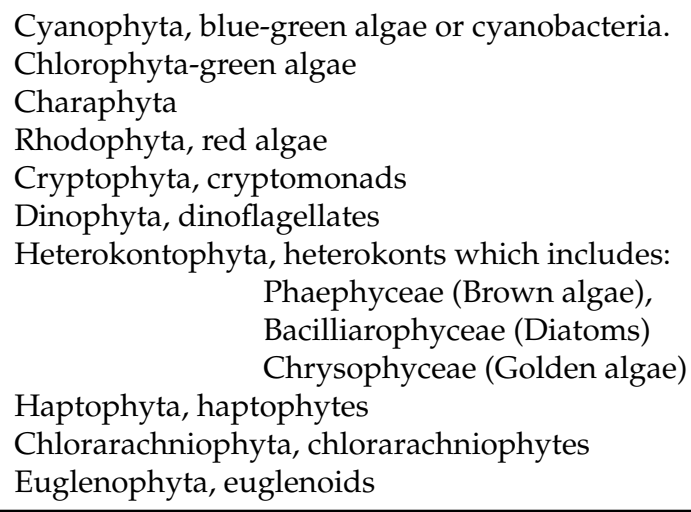

This classification is based mainly on a combination of ultrastructural and biochemical features. The terms 'microalgae' and 'macroalgae', whilst of no taxonomic value, are useful concepts to divide this diverse group of organisms into functional categories. Microalgae (often single cells or clusters of cells) have received considerable attention for high value product generation [14] (e.g., astaxanthin, polyunsaturated fatty acids). In addition, many have high lipid yields, making them suitable for use in biodiesel generation [15]. Macroalgae, on the other hand, are often rich in carbohydrates and low in lipids and are sometimes referred to as 'seaweeds' though this is not strictly true. They are largely used as food sources and grown on an industrial scale, particularly in the Far East, including China and Indonesia [16].

\section{Growing Algae-Requirements and Cost Implications}

\subsection{Macroalgae Production}

By 2025, world production of seaweeds is forecasted to reach US $\$ 30.2$ billion compared with US\$ 6 billion in 2014 (FAO, Food and Agriculture Organization ${ }^{\mathrm{P}}$ ), with $95 \%$ of this production coming from Asia. China alone accounts for $57 \%$ of the world production of algae (in 2018), with Indonesia also being a major producer (29\%) (Table 2). 
Table 2. Global production of algae. $\left({ }^{\mathrm{T}}\right.$ modified from FAO, 2018).

\begin{tabular}{ccc}
\hline Country & Seaweed Production (Million Tonnes) & World Production (\%) \\
\hline China & 18,506 & 57.3 \\
Indonesia & 9320 & 28.9 \\
Republic of Korea & 1711 & 5.3 \\
Phillipines & 1478 & 4.6 \\
DPR Korea & 553 & 1.7 \\
Japan & 89 & 1.2 \\
Malaysia & 174 & 0.5 \\
Zanzibar/Tanzania & 103 & 0.3 \\
Chile & 21 & $<0.1$ \\
Vietnam & 19 & $<0.1$ \\
India & 5 & $<0.02$ \\
Russian Federation & 5 & $<0.02$ \\
Others & 21 & $<0.1$ \\
\hline
\end{tabular}

Currently, more than 500 species of seaweeds, belonging to 100 genera, are collected and utilized, although only 33 genera of seaweeds (mainly red and brown) are harvested and/or farmed commercially worldwide [17] and some of the major crops are listed in Table 3. Eucheuma sp are harvested for carrageenan and account for over a third of all algae grown, with Laminaria japonica cultivated for human food being in second place.

Gracilaria is grown mainly for agar production, with particularly important economic value to Chile [18]. Overall, about $80 \%$ of macroalgae produced is used for human consumption (particularly in the Far East) or for flavouring. The remaining 20\% is used for extraction of hydrocolloids, animal feeds, and fertilizers [19]. Red and brown seaweeds account for $97.4 \%$ of global production [20], with red seaweed production up by $84 \%$ in the period 2010-2014 and predicted to continue to be the biggest growth sector up to 2025 . Brown seaweed production has also increased by $47 \%$ in the same period. Contrarily, global green seaweeds production decreased 30\% between 2010-2014. Africa produces mainly red seaweeds, while Europe mainly produces brown. Asia and America produce both red and brown seaweeds, although the former has seen an increase in red seaweeds production in recent years. In Europe, Canada, and Latin American, seaweed industries still rely largely on harvesting natural resources [21].

Table 3. Major species of macroalgae cultivated and their main products harvested. Modified from [20].

\begin{tabular}{lcc}
\hline \multicolumn{1}{c}{ Species } & \% World Production & Major Product Harvested \\
\hline Eucheuma sp & 34 & Carrageenan \\
Laminaria japonica & 28 & Human food \\
Gracilaria sp & 14 & Agar \\
Undaria pinnatifida & 9 & Human food \\
Porphyria sp & 7 & Human food \\
Kapphaphycus alvarezii & 6 & Carrageenan \\
Sargassum fusiforme & 1 & Human food \\
Others & & \\
Macrocystis pyrifera & & Alginate \\
Enteromorpha clathrate & $<1$ & Bioactive \\
Codium fragile & & Skin care \\
Monostroma nitidum & & Human food \\
Chondracanthus chamissoi & & Human food \\
\hline
\end{tabular}

Macroalgae are generally harvested in coastal waters so there are no costs associated with nutrient supply for growth, and the main costs are labour-related harvesting. Expansion of seaweed production would benefit from a better understanding of operational costs, yields, and ecological impact of seaweeds farms, as well as regulatory factors such as marine licensing laws [22]. 


\subsection{Microalgae Production}

Algae are eukaryotic photosynthetic organisms that utilise their photosynthetic capability to fix $\mathrm{CO}_{2}$, initially into carbohydrate precursors, and then metabolise these into the whole spectrum of macromolecules found in plant cells, such as membrane and storage lipids, proteins, nucleic acids, and polysaccharide cell walls. This type of growth is sometimes referred to as autotrophic growth. It is useful for synchronising growth as most cells divide at the same time leading to a step-wise increment in the population, e.g., Chlorella vulgaris [23]. However, many algae can be grown in no or low light conditions where they will utilise an external carbon source such as acetate or glucose for growth in much the same way as animal cells would, and this is referred to as heterotrophic growth [24]. Commonly, both autotrophic and heterotrophic approaches are used together, i.e., providing a light and external carbon source, and this is called mixotrophic growth. Chlamydomomas reinhardtii, for example, is commonly grown in Tris-acetate-phosphate (TAP) medium together with light exposure $[25,26]$. The cells divide rapidly and asynchronously reaching saturation $\left(35 \times 10^{6}\right.$ cell $\left.\mathrm{mL}^{-1}\right)$ within $4-5$ days. Recently, the addition of phenolics (particularly salicylic acid and aspirin) have been shown to stimulate cell division significantly in Chlamydomomas and may be a useful tool to achieve higher biomass in a shorter time period [26]. In Chlorella, growth rates show a doubling time of $\sim 8 \mathrm{~h}$ [27]. The fastest growing alga is Picochlorum renovo that has a double time of just $2.2 \mathrm{~h}$, which is $\sim 5-10$ times faster than many algae [28]. Commercially, the scale up of autotrophic cultures for industrial use is time consuming and requires a significant area for production plants. However, growing an inoculum heterotrophically, which, although carries an initial higher cost, markedly increases cell densities and reduces subsequent production times. This approach has been suggested for the scale up of Chlorella for 'seeding' photobioreactors for industrial scale production [29].

\subsection{Economics of Microalgae Production}

In contrast to macroalgal farming, the cultivation of microalgae is typically more controlled by using either open raceway ponds with stirrer paddles to aid circulation or else enclosed photobioreactors using polyethylene or tubular constructions [30]. No industrial scale plant exits dedicated to algal biofuel production, so economic assessment is largely based on laboratory scale up or commercial systems geared to the production of high value products. A useful assessment method is termed net energy ratio (NER) of biomass products [1] and is defined as the sum of the energy used for cultivating, harvesting, and drying divided by the energy content of the dry biomass. NER values $<1$ indicates a process which produces more energy than it consumes. Using this approach, in general, raceway ponds typically have NER $<1$, whereas photobioreactors are $>1$, thus favouring the former as the method of choice.

Improved economics could be achieved by using a low-cost water supply, readily available $\mathrm{CO}_{2}$, nutrients, and solar radiation of $<3000 \mathrm{~h} \cdot \mathrm{yr}^{-1}$. This latter point favours the set up of production sites in regions between approximately $30^{\circ}$ north and $30^{\circ}$ south of the equator [1]. Low cost water supplies could include seawater or brackish water or non-potable water where the algae could also serve a bioremediation role [31]. Marginal land would be preferable so as not to compete with food production and the topography not elevated from the water source, as this will incur a $6 \%$ consumption of energy in pumping for every $100 \mathrm{~m}$ elevation [32]. Carbon dioxide, purified from power stations, could be used, or better still the untreated flue gas, though this may contain contaminants which negatively impact algal growth [33]. It has been estimated that to replace fossil fuel with algal biomass for the EU alone, 25 million tonnes of nitrogen and 4 million tonnes of phosphorus per annum would be required. This is more than double the current EU capacity for fertilizer production. The base cost of production in an idealised raceway pond is estimated to be $\sim 1.6-1.8 € \cdot \mathrm{kg}^{-1}$ (with $\mathrm{CO}_{2}$ being $~ 50 \%$ of the costs) with projected costs, through cheaper sources of inputs dropping to $\sim 0.3-0.4 € \cdot \mathrm{kg}^{-1}$ [2]. To mitigate costs further, nutrients could be found in lower-value sources like wastewaters such as poultry litter or 
milk waste, which can greatly reduce the water and fertilizer demands for algal culture, and their integration for biofuel production has been strongly promoted recently [34]. Many algae require other specialist additions to the medium, e.g., diatoms which contain an outer 'shell' of silica will require this element to be added to the growth medium [35]. Algae that grow in brackish or highly saline media will require additional $\mathrm{NaCl}$, such as Dunaliella [36]. In addition to macronutrient requirement (N, P, K), optimal growth may require supplementation with a wide range of micronutrients such as those found in Hutner's trace elements solution that contains $\mathrm{H}_{3} \mathrm{BO}_{3}, \mathrm{ZnSO}_{4}\left(7 \mathrm{H}_{2} \mathrm{O}\right), \mathrm{MnCl}_{2}, \mathrm{CoCl}_{2}$, $\mathrm{FeSO}_{4}, \mathrm{CuSO}_{4}$, and $\left(\mathrm{NH}_{4}\right)_{6}\left(\mathrm{Mo}_{7} \mathrm{O}_{2}\right)_{4}$ [25]. Optimising nutrient strategies for microalgal cultivation has recently been reported for the production of biofuel substrates like starch and lipids [37].

\subsection{Potential Areas for Mass Algal Production for Global Biofuels Production}

Estimations of biofuel production vary widely and by orders of magnitude. A figure that is generally quoted is $5000-10,000$ gallons $\cdot \mathrm{acre}^{-1} \cdot \mathrm{yr}^{-1}$ (equivalent to $4.7-9.4$ million $\mathrm{L} \cdot \mathrm{km}^{-2}$ ), though a figure of $8027 \mathrm{million} \mathrm{L} \cdot \mathrm{km}^{-2}$ has been touted (BARD Algae, 2009). For microalgal biofuel production to reach 10\% of EU transportation fuel demand, an area three times the size of Belgium (equivalent to $\sim 92,000 \mathrm{~km}^{2}$ has been reported (Flynn K, 2017-web page link). In order not to compete with food or impinge upon urban areas, deserts with oceanic coast lines and low population density could be considered. Among these are the Arabian Desert (2.3 million $\left.\mathrm{km}^{2}\right)$, the Namib Desert $\left(81,000 \mathrm{~km}^{2}\right)$, and the Kutch district, Gujarat, India $\left(46,000 \mathrm{~km}^{2}\right.$, of which $7500 \mathrm{~km}^{2}$ is desert).

The Arabian Desert has two coastal regions, the Red Sea and the Persian Gulf [38]. In the former, winter temperatures are lower in January in the northern area (Al Wajh) $18{ }^{\circ} \mathrm{C}$, while in the southern region (Jizan) it is $\sim 27^{\circ} \mathrm{C}$ at this time. August mean temperatures are in the region of $30-34^{\circ} \mathrm{C}$, though much higher are often recorded. On the Persian Gulf side, higher average summer temperatures of $\sim 37^{\circ} \mathrm{C}$ are recorded. Average rainfall per year over the region is $<100 \mathrm{~mm}$, though regional variation is apparent. Growing algae in open raceway ponds at depths of typically $0.5 \mathrm{~m}$ would present challenges with evaporation and salt concentration if using seawater.

The Namib Desert in southern Africa is the world's oldest desert and lies on the western coast at the tip of the continent [39]. Rainfall is sparse and highly unpredictable, ranging from $5 \mathrm{~mm}$ in the west to $85 \mathrm{~mm}$ on the eastern flank. Temperatures are much cooler than those of the Arabian Peninsula, with mean coastal temperatures in the region of $10-16^{\circ} \mathrm{C}$, although inland areas reach low thirty degrees in the summer. Much of the coastal region is frequently covered in fog and the Atlantic winds have created sand dunes up to $300 \mathrm{~m}$ high. Productivity could be impeded at low temperatures and for every $100 \mathrm{~m}$ in height above sea level there is a $6 \%$ energy cost of algal biomass, raising additional challenges. In addition, the expansion of the desert into the sea would present long term challenges for the establishment of an algal plant facility.

The Gulf of Kutch, in Gujarat, in the north western region of India, is highlighted as an area for tidal energy generation [40]. The average rainfall is higher than both the Arabian Desert and Namib Desert at $140 \mathrm{~mm}$ per year, with an average mean temperature of $28^{\circ} \mathrm{C}$. These two factors make it more suitable geographically for growing microalgae, though the infrastructure on the Arabian Peninsula for process oil is well advanced and would offer other advantages.

For biofuel production, therefore, algae that can grow in seawater, tolerate high temperatures, and have high lipid contents $(>50 \%)$ would be primary candidates. At present, microalgae are grown commercially for their high value products and not as sources of biofuel and the main species are listed in Table 4 and have multiple applications in human nutrition as food supplements or as nutraceuticals. 
Table 4. Main cultivated microalgal species and their key products. Modified from [41].

\begin{tabular}{|c|c|c|c|}
\hline Species & Phylum & Product & Application \\
\hline Arthrospira platensis & Cyanophyta & Phycocyanin, biomass & Health food, cosmetics \\
\hline Aphanizomenon flos-aquae & Cyanophyta & Protein. Essential fatty acids, $\beta$-carotene & Health food, food supplement \\
\hline Lyngbya majuscule & Cyanophyta & Immune modulators & Pharmaceuticals, nutrition \\
\hline Chlorella spp & Chlorophyta & Biomass, carbohydrate & Animal nutrition, food supplement \\
\hline Dunaliella salina & Chlorophyta & carotenoids & Health foods \\
\hline Haematococcus pluvialis & Chlorophyta & astaxanthin & Pharmaceuticals, feeds \\
\hline Scenedesmus spp & Chlorophyta & Protein & Aquaculture, human nutrition \\
\hline Odontella aurita & Heterokonta- & EPA & Pharmaceuticals, cosmetics \\
\hline Phaedactylum tricomutum & Heterokonta & Lipids, fatty acids & Nutrition, fuel production \\
\hline Schizochytrium spp & Heterokonta & DHA and EPA & Food supplement, beverage \\
\hline Nannochloropsis oculata & Heterokonta & biomass & Larval/juvenile marine fish food \\
\hline Nannochloropsis spp & Heterokonta & EPA & Pharmaceuticals food supplement \\
\hline Porphyridium cruentum & Rhodophyta & polysaccharides & Pharmaceuticals, cosmetics \\
\hline Isochrysis galbana & Haptophyta & Fatty acids & Animal nutrition \\
\hline Crypthecodinium cohnii & Dinoflagellata & DHA & Infant health and nutrition, brain development \\
\hline
\end{tabular}

\section{Harvesting, Dewatering, and Drying of Microalgae}

Harvesting and dewatering costs have been estimated to be in the range of 20-30\% of total production costs, but recent modelling has put this figure much lower and in the range of $3-15 \%$, with values in the range of $0.5-2 € \cdot \mathrm{kg}^{-1}$ of algae and $0.2-5 \mathrm{kWh} \cdot \mathrm{kg}^{-1}$ algae for dilute cultures from open raceway ponds. For closed systems of the PBR-type, the costs decrease to $0.1-0.6 € \cdot \mathrm{kg}^{-1}$ and energy costs to $0.1-0.7 \mathrm{kWh} \cdot \mathrm{kg}^{-1}$ [2]. However, the capital costs of the latter exceed those of the open pond systems. Although high cell densities cultures can be achieved, the bulk of the culture is actually the aqueous phase. So, in open ponds, yields are often in the region of $0.5 \mathrm{~g} \cdot \mathrm{L}^{-1}$, and for photobioreactors $\sim 5 \mathrm{~g} \cdot \mathrm{L}^{-1}$ giving $\%$ yields of $0.05-0.5 \%$ of the total weight of the culture [42]. Inevitably, this will require the separation of the biomaterial from the aqueous phase. This can be achieved in several ways, but each will carry a cost consideration and or a contamination challenge that needs to be overcome. Four main procedures are typically deployed [43,44], namely, centrifugation, flocculation (induced by either chemical and/or biological agents), froth flotation, and physical methods. It should be noted that centrifugation is still generally required after flocculation, so these two methods are co-deployed.

\subsection{Centrifugation}

Because of the density of the cells, centrifugation to sediment the cells as a pellet need only be low speed. In the lab, typically this is around 500-1000 $\mathrm{g}$ for a few minutes (where $\mathrm{g}$ is the force per unit mass due to the gravity at the Earth's surface) [45]. The aqueous phase can they be decanted off. When microalgae are produced for high-value products, harvesting is done by centrifugation. The advantages of centrifugation are that it can be used continuously for large scale processing with high recoveries, however, the capital costs are too expensive and energy-intensive if biomass is to be used for low-value products such as biofuels. To overcome this, flocculation could be deployed.

\subsection{Flocculation}

This involves the aggregation of cells together in clusters and leads to precipitation from the water phase. The principle of flocculation lies in the observation that algal cells display an overall net negative charge on their surface and hence repel each other in suspensions [43]. Once neutralised, the cells collide and agglomerate under Van der Vaals forces, resulting in precipitation. Chemicals or other agents (e.g., biological agents) can facilitate this neutralisation of charge and so bring about cell clustering. Sometimes this phenomenon can be observed by the simple interruption to the supply of $\mathrm{CO}_{2}$ (which causes an increase in $\mathrm{pH}$ ) to the medium, and this results in the spontaneous aggregation of cells (typical pH > 9.0) called auto-flocculation and is indeed the cheapest approach, since nothing else is required. However, not all cultures auto-flocculate and so have to be encouraged to do so by chemical application such as chitosan, alum, and ferric chloride. 
Chitosan is a derivative of chitin, the polysaccharide that forms the exoskeleton of arthropods such as crustacea and insects. It consists essentially of a cellulose structure involving $\beta-1,4$ linkages of glucose in which the $\mathrm{C} 2-\mathrm{OH}$ is replaced with an acetylated amino group (Figure 1).

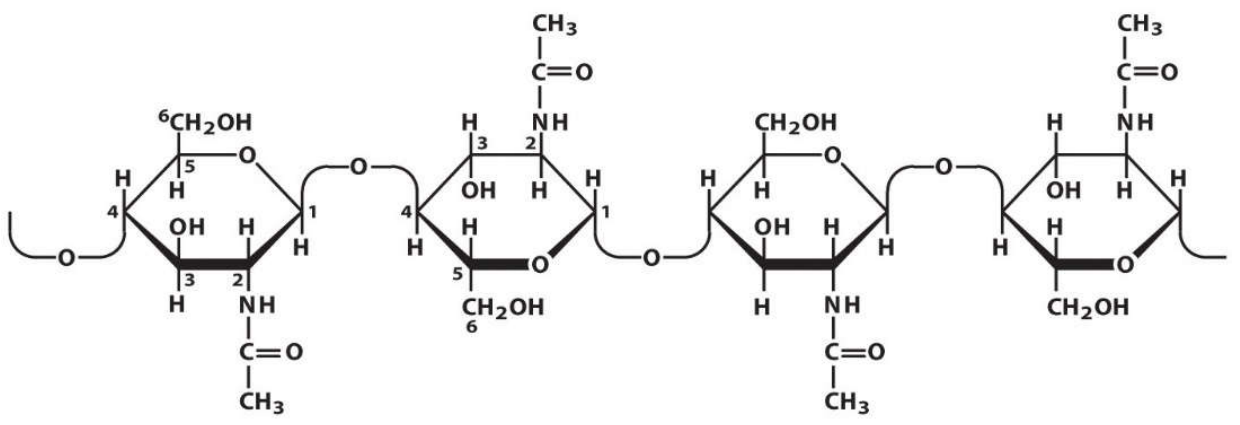

Figure 1. Structure of chitin.

Chitosan is formed from the de-acetylation of the chitin and is a positively charged biopolymer [46]. Chitosan is a very efficient flocculant but it works only at low $\mathrm{pH}$, but $\mathrm{pH}$ in microalgal cultures is relatively high [47]. Other flocculating agents alternatives include cationic starch [43], which works over a broader range than chitosan [28] and poly-gamma-glutamic acid (produced by Bacillus subtilis) [48].

Microalgae flocculation can also occur naturally caused by extracellular polymers and/or info-chemicals secreted into the medium, and this is called bio-flocculation [49], with some species flocculating more readily than others [50]. Info-chemicals have been identified in terrestrial plants such as methyl jasmonate that signal herbivorous attack between plants [51]. Since algae also contain a range of phytohormones, in principle, these could have roles in intercellular communication in the aquatic environment. Phenolic compounds are known to control the rate of cell division in Chlamydomonas and are particularly stimulated by salicylic acid [26]. Other biological agents in the water column such as bacteria and fungi can also induce bio-flocculation of microalgae. This opens the possibility of adding such biological agents to microalgal cultures and inducing flocculation without recourse to using chemical treatments that may have benefits but could also interfere with other applications, especially when used for human products or as feeds.

The term 'alum' usually refers to a hydrated double sulphate salt of aluminium with the general formula XAl $\left(\mathrm{SO}_{4}\right)_{2} \cdot 12 \mathrm{H}_{2} \mathrm{O}$, where $\mathrm{X}$ is a monovalent cation such as potassium or ammonium with the former being the most widely used [52]. This pre-concentration of cells could significantly reduce operational costs, but centrifugation is still necessary. Flocculation typically increases the concentration by a factor of 20-100 resulting in the formation of a slurry of $10-50 \mathrm{~g} \cdot \mathrm{L}^{-1}$ and makes the subsequent centrifugation step more cost effective because the aggregates are large and the volume of water to be processed is lower. However, the use of metal complexes leads to their elevated levels in algal biomass and this may have a negative impact on their intended use (e.g., as feed) or as feedstock for bioenergy, where the presence of metals ions has been shown to have a negative impact on pyrolysis.

The $\mathrm{Ca}^{2+}$ ions of calcium phosphate agglomerate cells by binding to their negatively charged surfaces [53]. However, the declining phosphate reserves coupled with increased cost of purchase make this an unsustainable approach. Magnesium hydroxide or brucite could be used, as the $\mathrm{Mg}^{2+}$ also flocculates cultures by forming inorganic precipitates. Although these have a low toxicity, it is nevertheless preferable to remove them.

In summary, flocculation has a low energy demand and low equipment cost but its drawback is the recovery of flocculants. Therefore, in terms of overall costs it is similar to mechanical harvesting. 


\subsection{Froth Flotation}

Froth flotation is a process developed for the separation of minerals, however, its principles can be exploited to achieve separation of particles in the size range form 50-400 microns which includes microalgae [44]. It relies on the hydrophobic surface chemistry and when air bubbles are passed through the sample that bind to these surfaces brings about separation of cells into a foam at the surface. Enhanced flotation recovery of $>98 \%$ has recently been reported by the combined use of $\mathrm{Al}^{3+}$ as a coagulant combined with cetyltrimethylammonium bromide (CTAB) [54]. Economic assessment of these methods is ongoing.

\subsection{Physical Methods}

Electromagnetic pulses to neutralise the surface charge of microalgal cells and induce flocculation have been demonstrated. Magnetic nanoparticles have also been investigated to harvest microalgae. Magnetite $\left(\mathrm{Fe}_{2} \mathrm{O}_{3}\right)$ nanoparticles adsorbed directly onto cell surfaces can be separated from the medium by applying a magnetic field, combining flocculation and separation into a single process [55]. Variations in adsorption between species have been observed and can be improved by coating the nanoparticles with cationic polymers. Importantly, nanoparticles can be recovered after harvesting and subsequently re-used [56].

Despite the numerous harvesting methods that are possible and listed above, currently no large scale assessment has been undertaken to compare these methods and to perform mass and energy balance calculations [57]. Therefore, comparative technique studies at scale will need to be undertaken to address this knowledge gap.

\section{Added and High-Value Products from Algae}

Whilst the focus of this review is on biofuels, it is important to recognise that algae are a major source of many important products used in the cosmetic, pharmaceutical, and nutraceutical sectors and command a significant price. Thus, it is conceivable that biofuels could be generated as co-products or by-products of these industries, thus leading to subsidising the costs for biofuel production. Base commodities such as fuels/energy, feed, and bioremediation are considered high volume low cost $(<£ 1 \cdot \mathrm{kg})$, while added value chemicals can fetch $£ 1-5$, and specialty products $£ 5-1000 \cdot \mathrm{kg}^{-1}$ or in the case of nutraceutical/cosmeceuticals applications often $>£ 2000 \cdot \mathrm{kg}^{-1}$. Currently, the UK capacity for seaweed production is 'positioned' between the 'added value commodities' and 'specialty products', with values between $£ 1-1000$ per $\mathrm{kg}$. A comprehensive coverage of the range of products extracted and used from algae is outside the scope of this review, so instead it will focus on some key developments in this sector. Some of the major products are used for health food supplements (e.g., omega-3-fatty acids), food and other ingredient additives (hydrocolloids), and bio-actives used in the cosmeceuticals and nutraceuticals industries (e.g., astaxanthin).

\subsection{Omega-3 Fatty Acids}

Arachidonic acid, AA $\left(20: 4 \Delta^{5,8,11,14}\right)$, eicosapentaenoic acid, EPA $\left(20: 5 \Delta^{5,8,11,14,17}\right)$, and docosahexaenoic acid, DHA $\left(22: 6 \Delta^{5,8,11,14,17,19}\right)$, are essential fatty acids required for neurological development, especially in neonates, and play a crucial role in maintaining a healthy immune system [58]. Microalgae are the primary producers of omega-3 fatty acids (Figure 2) in the marine eco-system and can be produced from both photoautotrophic (e.g., Nannochloropsis, Tetraselmis, Isochrysis, Pavlova, and Phaeodactylum) and heterotrophic (e.g., Schizhochytrium, Crypthecodinium) modes of cultivation. Despite extensive research on production of AA/EPA/DHA from microalgae, production at a commercial scale is still in its infancy and represents only a small share in the market and remains expensive compared to fish oil. The price of EPA/DHA produced from microalgae is $\sim \$ 1500$ per $\mathrm{kg}$, whereas the fish oil-based product is $\sim \$ 750$ per $\mathrm{kg}$. This is due to the fact the microalgae require supplementation of heavy loads of organic carbon and use energy intensive downstream processing techniques, such as centrifugation and high pressure homogenisation. 


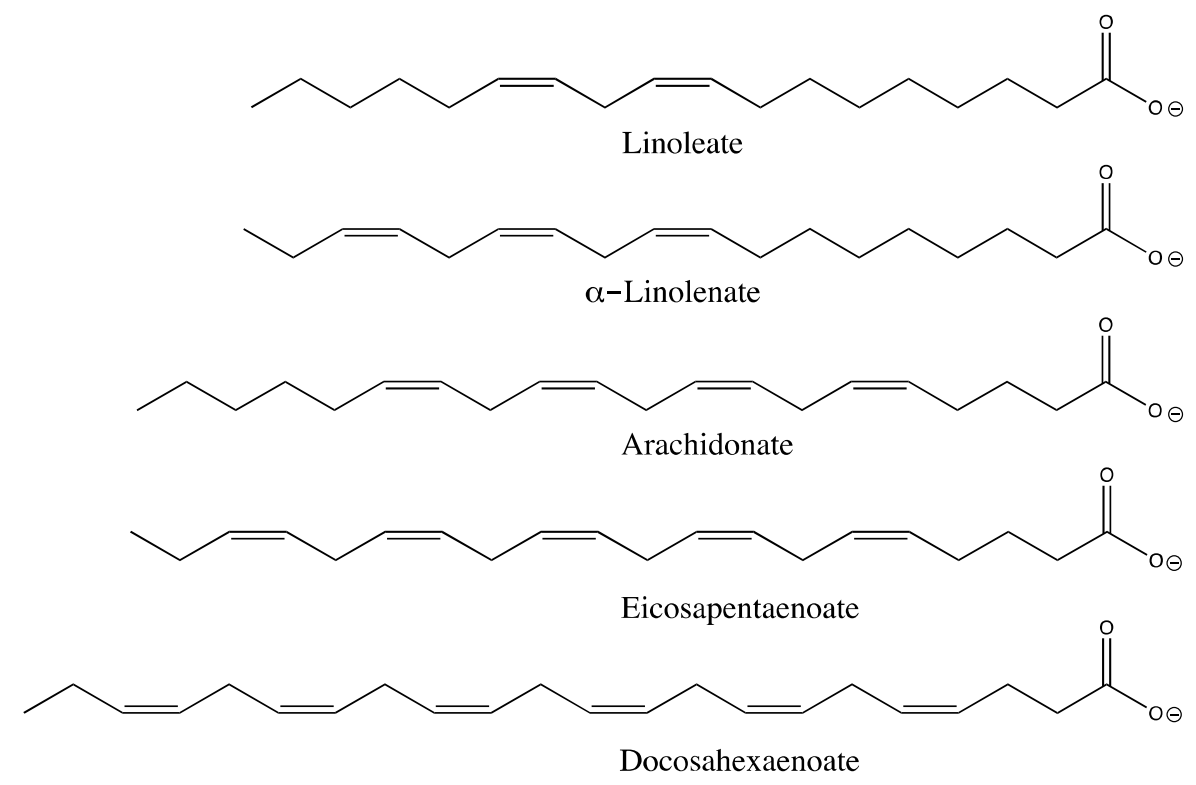

Figure 2. Structures of major polyunsaturated fatty acids found in many algae.

\subsection{Squalene}

Squalene $(2,6,10,15,19,23$-hexamethyl-6,6,10,14,18,20-tetracosahexene) is a naturally occurring triterpenoid with the molecular formula $\mathrm{C}_{30} \mathrm{H}_{50}$ synthesised from isoprene, a C5building unit derived from mevalonic acid $[59,60]$. Squalene has many beneficial properties and appears to act as a natural antioxidant because it acts as an effective quencher of singlet oxygen and lowers lipid peroxidation, hence its use in anti-aging skin creams [61]. It is widely considered to be the active ingredient in olive oil and could play a key role in the healthy Mediterranean diet. Squalene is present in high quantities in deep-sea sharks and accounts for $40-70 \%$ of shark liver oil and about $50 \%$ of global production [62]. However, the widespread killing of sharks for their liver has attracted negative press and alternatives are actively being sought. Squalene is present in vegetable oils and is extracted commercially from olive oil [63], which contains $564 \mathrm{mg}$ per $100 \mathrm{~g}$. Significant levels of squalene have been detected in microalgae and macroalgae [64], and these could be a future source of this product if rapid screening methods could be developed to identify high yielding algae. Alternatively, improving squalene production through up-regulation of genes that lead to its synthesis or down-regulation of genes for its degradation is possible [60].

\subsection{Pigments}

Algae contain a wide variety of pigments, such as chlorophyll ( $a, b$, and c), carotenoids, and phycobiliproteins, which exhibit a range of colours [65]. Concerns around the safety of synthetic dyes has led to a societal shift towards the use of natural sources from plants and algae and are being used in nutraceutical, cosmetics, and pharmaceutical industries.

Astaxanthin (ASX), a xanthophyll carotenoid, is a secondary metabolite naturally synthesised by a number of bacteria, microalgae, and yeasts. The unicellular green microalgae Haematococcus pluvialis, with an ASX content of $1-5 \%$, is recognised as the best biological source of this compound and is the only commercialised microalga used to produce it [66]. ASX possesses various health benefits and has been shown to have important dermatological applications. ASX has also been approved as a colour additive in fish feeds and as a dietary supplement for human consumption, with an advised daily intake of $0.034 \mathrm{mg} \cdot \mathrm{kg}^{-1}$ body weight [67]. In addition, supercritical $\mathrm{CO}_{2}$ extracts from H. pluvialis have been granted "novel food" status by the Food and Drug Administration (Silver Spring, MD, USA). 
Phycoerythrin (PE) is a red protein-pigment complex from the light-harvesting phycobiliprotein family, present in red algae [68] and cryptophytes, and is an accessory pigment to chlorophyll, the primary photosynthetic pigment. It is composed of a protein to which is covalently bound a chromophore called phycobilin. Unlike chlorophyll, in which the chromophore tetrapyrrole ring is a closed macrocyclic ring, chelating $\mathrm{Mg}$ at the centre, in $\mathrm{PE}$ it is an open chain tetrapyrrole lacking a bound metal. Porphyridium marinum could be potentially used as a source of bioactive phycoerythrin protein for a wide range of applications in fluorescence spectroscopy, as a colour agent for milk-based products, and more widely in cosmetic and pharmaceutical applications [69].

Phycocyanin is a pigment-protein complex from the light-harvesting phycobiliprotein family, along with allophycocyanin and phycoerythrin, and is an accessory pigment [70]. All phycobiliproteins are water-soluble, in contrast to carotenoids that are hydrophobic and form clusters that adhere to the membrane called phycobilisomes. Phycocyanin is typically light blue in colour, absorbing orange and red light, particularly near $620 \mathrm{~nm}$, and emits fluorescence at about $650 \mathrm{~nm}$.

\subsection{Hydrocolloids}

Hydrocolloids are used in the food, cosmetic, and medical industries [71]. Alginates and fucoidan are extracted from brown seaweeds, while carrageenan and agar are extracted from red seaweeds [72]. These three polysaccharide components bind water and form hydrogels, which are then used as additives and stabilizers in different market sectors. Alginates are used in food and drink products as thickeners, gelling, and stabilizers, while carrageenans are used in the dairy sector as stabilizer [73]. Other industrial uses include shampoos and toothpastes. Agar (Agarose) is a versatile food addictive (thickening and emulsifying agent) as it has no taste, smell, or colour, and is widely used as laboratory cultivation medium for microbes.

\subsection{Phlorotannins}

Phlorotannins are metabolites of brown algae that have gained particular attention due to their specific bioactivities that include antioxidant, antiproliferative, or antidiabetic properties and hence are of pharmacological interest [74]. They are generally dark brown in colour and are responsible for the poor digestibility of seaweeds in AD reactors [75]. Hence, their extraction from the tissue prior to AD not only aids that process but also generates an important chemical stream for potential human health applications. The underpinning chemistry relates to the phenolic rings acting as stabilisers for free radicals through the delocalised $\pi$ electron system, thus reducing the propagation of undesirable reactions.

\section{Types of Biofuel from Algae}

\subsection{Bioethanol}

In the USA, corn is the major feedstock for ethanol production, while in Brazil it is sugarcane. These countries combined account for $\sim 84 \%$ of global ethanol production, with the EU being at $\sim 5 \%$ (Table 5).

Table 5. Major global producers of bioethanol ( ${ }^{\mathbb{I}}$ from afdc.energy.gov, accessed on 19 September 2021).

\begin{tabular}{cc}
\hline Country & Production 2019 (Billions L) \\
\hline USA & 15.78 \\
Brazil & 8.57 \\
EU & 1.44 \\
China & 0.90 \\
Canada & 0.50 \\
Rest of the World & 1.84 \\
\hline
\end{tabular}


The yield of ethanol $\left(\mathrm{L} \cdot \mathrm{ha}^{-1}\right)$ varies from crop to crop, e.g., wheat $\left(2590 \mathrm{~L} \cdot \mathrm{ha}^{-1}\right)$, cassava (3310 L·ha ${ }^{-1}$ ), corn (up to $4020 \mathrm{~L} \cdot \mathrm{ha}^{-1}$ ), and sugar beet (up to $6680 \mathrm{~L} \cdot \mathrm{ha}^{-1}$ ) [76]. Algal yields are 7 to 21 times higher and in the range of 46,760-140,290 L·ha ${ }^{-1}$ ), making them prime targets for exploitation [3]. Microalgae are good sources of carbohydrate (predominatly starch) for fermentation such as Chlorella vulgaris (55\%), Chlamydomonas reinhardtii (60\%), Scenedesmus obliquus (52\%) [77], although cost factors in growth and harvesting are still currently prohibitive.

Bioethanol production from several macroalgae has also been reported [3] (Table 6). Ethanol yields on $\mathrm{g} \cdot \mathrm{g}^{-1}$ sugar basis vary from 0.14 to 0.47 and theoretical yields from as low as $28 \%$ (Ulva pinnatifida) to $92 \%$ Ulva lactuca and Gracilaria amansii. Gracilaria is grown principally for agar and the waste pulp is disposed of as waste. However, it contains sufficient cellulose that its fermentation with Saccharomyces cerevisiae can yield ethanol at levels similar to corn $\left(0.48 \mathrm{~g} \cdot \mathrm{g}^{-1}\right.$ sugar $)$ and newspaper waste $\left(0.39 \mathrm{~g} \cdot \mathrm{g}^{-1}\right.$ sugar) [78]. Again, there is no current commercial production of bioethanol from macroalgae due to prohibitively high production costs.

Table 6. Bioethanol yields from selected algae. Modified from [3].

\begin{tabular}{cccc}
\hline Group & Species & Ethanol Yield g. $\mathbf{g}^{-\mathbf{1}}$ Sugar & Theoretical Yield (\%) \\
\hline Chlorophyta & Enteromorpha intestinalis & 0.21 & 42 \\
& Ulva fasciata & 0.45 & 88 \\
& Ulva lactuca & 0.47 & 92 \\
Ulva pertusa & 0.47 & 91 \\
& & & 75 \\
& A. crassifolia & 0.38 & 84 \\
Rhodophyta & L. hyperborea & 0.43 & 69 \\
& S. sagamianum & 0.35 & 81 \\
& S. japonica & 0.41 & 28 \\
& U. pinnatifida & 0.14 & 74 \\
& G elegans & 0.38 & 92 \\
& G. amansii & 0.47 & 84 \\
& G. verrucose & 0.43 & 49 \\
K. alverzii & 0.25 & 34 \\
\hline
\end{tabular}

\subsection{Conversion of Sugars to Paraffins}

Sugars can also be used as a potential source of fuels through fermentation and hydroprocessing. Cellulose could supply monomeric glucose when hydrolysed, producing C6 glucose. Sugars are first fermented to iso-butanol then dehydrated to isobutene that then require oligomerisation and hydrogenation to yield C12 iso-paraffins [79] (Figure 3). To date, the entire process of converting algal sugars to jet fuel has not been fully documented. Recalcitrance of many macroalgae caused by the difficulties to ferment complex polysaccharide cell walls and the presence of inhibitors (e.g., phlorotannins in brown algae) makes starch-rich microalgae a better proposition as a feedstock for this process.

\subsection{Anaerobic Fermentation}

Anaerobic digestion (AD) is the degradation of organic matter from a range of feedstocks such as sewage, food waste, and agricultural residues into two principle products, namely, biogas and digestate (both solid and liquid states). Three phases are generally recognised in this process of transformation (Figure 4). 
Fermentable sugar

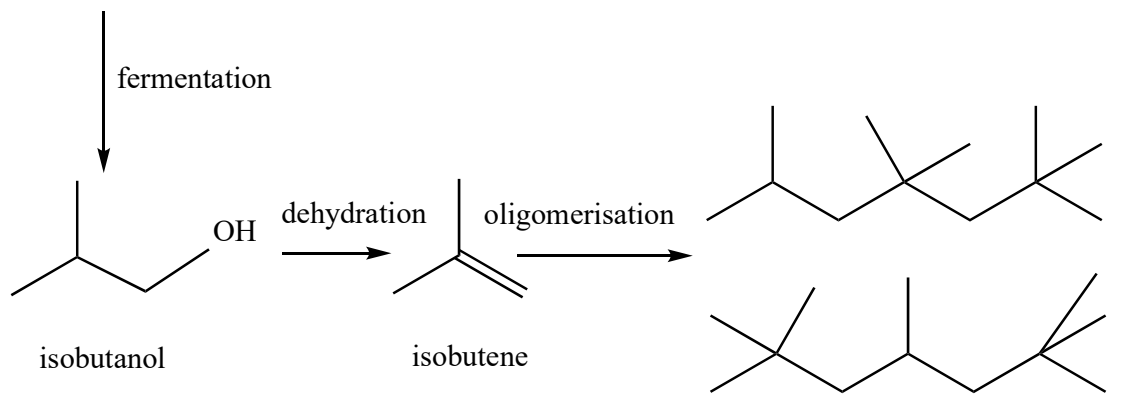

Figure 3. Conversion of isobutanol to isoparaffin. Modified from [80].

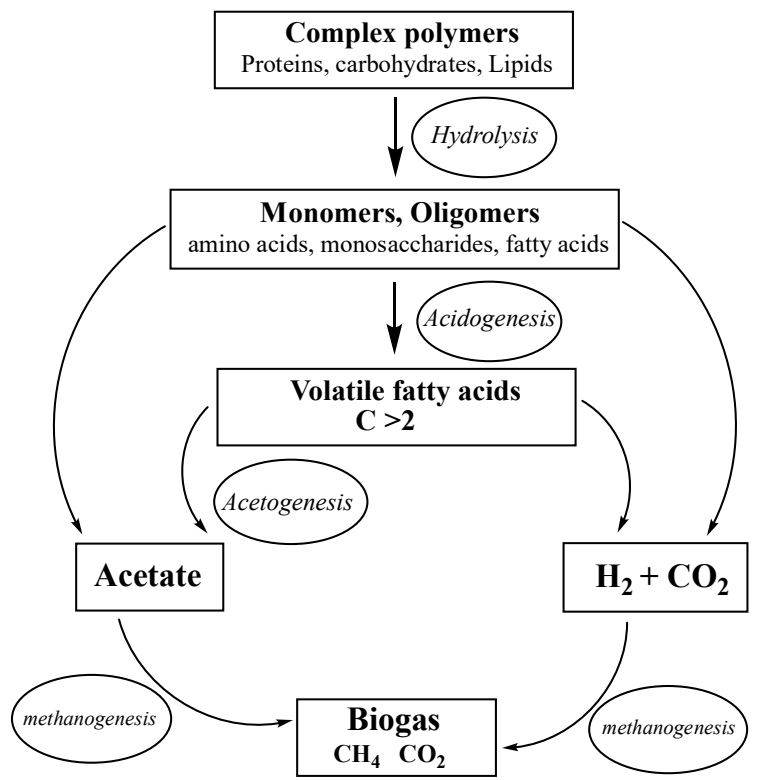

Figure 4. Anaerobic digestion process.

Phase 1 is the hydrolysis step which results in the generation of the monomeric building blocks, namely 'sugars' such as glucose, galactose, and fructose from polysaccharides and amino acids from cleavage of the peptide bonds in proteins. Lipids are de-esterified into their constituent fatty acids (typically $\mathrm{C}_{16}-\mathrm{C}_{18}$ chain length fatty acid) and glycerol or glycerol phosphate derived from phospholipids.

Phase 2, acidogenesis, is the generation of short chain fatty acids (monocarboxylic acids, sometimes called volatile fatty acids), e.g., propionate $\left(C_{3}\right)$, butyrate $\left(C_{4}\right)$, and valerate $\left(C_{5}\right)$ from precursor monomers of carbohydrate, protein, and lipid origin generated in phase 1 . The process of generating acetate $\left(C_{2}\right)$ is sometimes referred to separately as acetogenesis.

Phase 3 is the final step is the conversion of acetate to methane $\left(\mathrm{CH}_{4}\right)$ and is performed by methanogenic bacteria in the culture. The end products are, therefore, a complex mixture of organic molecules with the biogas being composed of varying proportions of $\mathrm{CH}_{4}$ and $\mathrm{CO}_{2}$ and $\mathrm{H}_{2}$. The proportion of $\mathrm{CH}_{4}$ in the biogas is estimated as the biomethane potential (BMP) of the feedstock. The biogas produced from the AD of seaweed typically contains $\mathrm{CH}_{4} 50-70 \%, \mathrm{CO}_{2} 30-45 \%, \mathrm{H}_{2}<2 \%$, and $\mathrm{H}_{2} \mathrm{~S}<3.5 \%$ [5]. Currently, acetic acid, butyric acid, and hydrogen are mostly produced by petrochemical reforming, and they serve as precursors of ubiquitous petrochemical derived products. Thus, AD is an important sustainable process that could be used for the synthesis of valuable chemicals, i.e., an alternative to a petrochemical refinery. 


\subsection{AD of Macroalgae}

The hydrolysis of seaweed cell walls that are composed of complex polysaccharides (e.g., alginates) is often a rate-limiting step in AD. Increasing the surface area for microbial attack through torrefaction is often performed to increase biomethane yield but also chemical pre-treatment, through acid digestion, is also frequently performed to increase digestibility [81].

$\mathrm{AD}$ is largely the method of choice for biomass of high-water content because it does not require de-watering and drying, which has associated energy costs. In addition, all the organic carbon is utilised rather than specific sub-sources such as oil for biodiesel formation, hence biogas systems tend to yield more energy per hectare than liquid biofuel systems [82]. Currently, biofuel from seaweed AD is perhaps the closest to industrial exploitation [5]. For example the gross energy yields from the cultivation and AD of Saccharina latissima, at $186 \mathrm{GJ} \cdot \mathrm{ha}^{-1} \cdot \mathrm{yr}^{-1}$, were higher than those based on the current liquid biofuel systems such as ethanol from sugarcane $\left(135 \mathrm{GJ} \cdot \mathrm{ha}^{-1} \cdot \mathrm{yr}^{-1}\right)$ and biodiesel from palm oil (120 GJ.ha $\left.{ }^{-1} \cdot \mathrm{yr}^{-1}\right)$ [5]. Overall, the energy potential of marine biomass is estimated to be $>100 \mathrm{EJ} \cdot \mathrm{yr}^{-1}$, with substantially lower yields for terrestrial biomass (22 EJ. $\left.\mathrm{yr}^{-1}\right)$ or municipal solid waste $\left(7 \mathrm{EJ} \cdot \mathrm{yr}^{-1}\right)$ [83].

Yields of biomethane from seaweed AD vary widely, mainly due to compositional differences, with brown algae generally producing higher yields than those from green algae. The yield of $\mathrm{CH}_{4}$ from a range of macroalgae is the region of 0.12 to $0.48 \mathrm{~m}^{3} \cdot \mathrm{kg}^{-1}$. VS (Table 7), where VS is the amount of volatile solids. Biogas yields from digestion of many algae are substantially below the theoretical maximum and typically $<50 \%$ of that from common commercial feedstocks, while BMP varies across species between $19-81 \%$ of theoretical yields [82]. There are several explanations for the low methane yield that include (a) cell wall structure, (b) polysaccharides that are not readily hydrolysed, (c) polyphenols, (d) organic sulphur compounds, (e) other antimicrobial and toxins, (f) C:N ratio, and (g) heavy metals [5].

A number of chemical constituents in seaweeds are known to inhibit AD, and pretreatment to remove them can lead to increased biomethane generation [84]. The high sulphur concentration in seaweed can also lead to the production of $\mathrm{H}_{2} \mathrm{~S}$ that lowers $\mathrm{BMP}$ and elevates $\mathrm{SO}_{2}$ emissions on biogas combustion [85]. The concentration of $\mathrm{H}_{2} \mathrm{~S}$ in biogas can be reduced by the addition of metal ions such as iron or by gas scrubbers, but both increase production costs. Phenolic compounds, which are particularly abundant in brown algae, also reduce the BMP of seaweed extracts and appear to have a negative impact on bacterial membranes and negatively affect degradation of the more complex polysaccharides rather than hydrolysis of simpler molecules [5].

A recent techno-economic assessment of seaweed feedstock for AD found that for seaweed combined with food waste, cattle slurry and grass, a financial incentive of between 0.85 and $1.17 € \cdot \mathrm{m}^{-3}$ was needed for viability, compared to the wholesale methane sales price of $0.2 € \cdot \mathrm{m}^{-3}$ [86]. Improving cell wall digestibility using tailored enzymes may help improve biomethane yields. A biomass productivity of over $73.5 \mathrm{t}$ dry mass $\cdot \mathrm{ha}^{-1} \cdot \mathrm{yr}^{-1}$ with a methane yield of $285 \mathrm{~m}^{3} \cdot \mathrm{t}^{-1}$ dry mass would make electricity production from macroalgae profitable, and this might be achieved using fast-growing macroalgae, such as Ulva [87].

Table 7. Biomethane yields from selected macroalgae. Modified from [82].

\begin{tabular}{cc}
\hline Genus & Methane Yield (L·g. VS $^{-\mathbf{1})}$ \\
\hline Gracillaria & $0.28-0.40$ \\
Laminaria & $0.23-0.30$ \\
Sargassum & $0.06-0.19$ \\
Macrocystis & $0.14-0.40$ \\
Ulva & 0.31 \\
\hline
\end{tabular}




\subsection{AD of Microalgae}

Whereas carbohydrates are the main constituents of macroalgae (typically $~ 50 \%$ ), microalgae are generally richer in proteins (up to $50 \%$ ) with significant levels of storage lipid (oils) ranging from $20-50 \%$ or even higher. The relative quantities of carbohydrates, proteins, and lipids affect BMP, with lipids giving higher yields [5]. Triglycerides and long chain fatty acids (LCFAs) have a high methane potential, but can cause blockages and inhibit bacterial growth [5]. A high protein content can reduce the $\mathrm{C}: \mathrm{N}$ ratio and lead to excessive (toxic) $\mathrm{NH}_{4}$ production from the degradation of amino acids and thereby result in lower methane production. However, despite these drawbacks, in general, higher biogas yields are reported for microalgae with yields of up to $88 \%$ of the theoretical methane potential [88]. As with macroalgae, cell wall degradability plays an important role with easily degradable species lacking a cell wall (e.g., Dunaliella salina) or a proteinbased cell wall lacking hemicellulose or cellulose (e.g., Chlamydomonas reinhardtii), Euglena gracilis) having a higher BMP than species containing these components, e.g., Parachlorella kessleri and Scenedesmus obliquus [89]. The study suggests that various pre-treatment steps are required to enhance the hydrolysis and promote $\mathrm{AD}$. Indeed, $\mathrm{CH}_{4}$ from $\mathrm{AD}$ of algae residues after lipid removal is required for net gains in energy and AD is a vital part of algal biodiesel processing [5]. Recently, we have shown that AD pre-treatment of seaweeds resulted in the subsequent generation of bio-oil, with characteristics more similar to petroleum with increased aromatic content and decreased anhydro-sugar content (Wahab M et al., in press Figure 5).

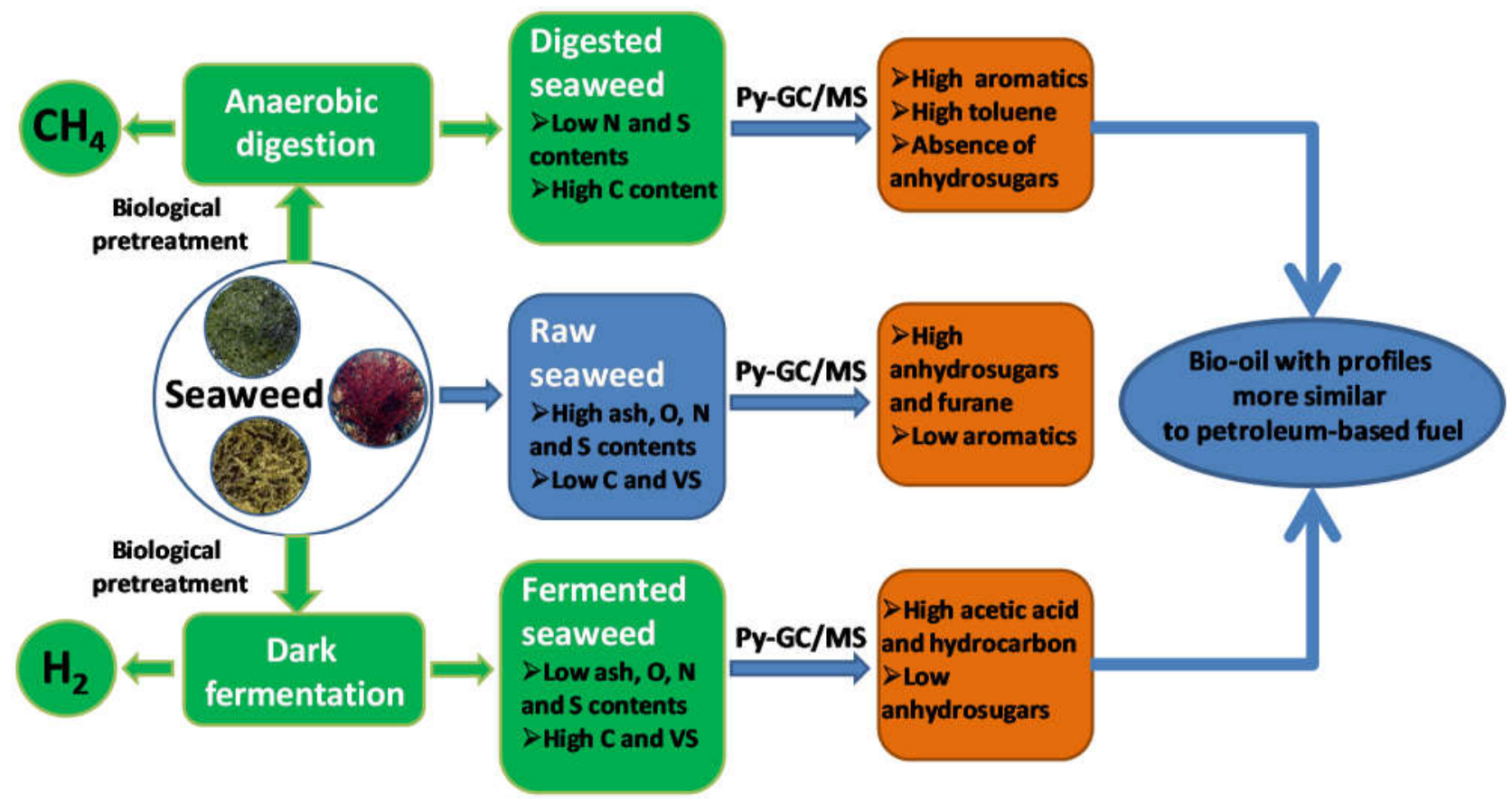

Figure 5. Pre-treatment of algal biomass to improve bio-oil quality.

\subsection{Biohydrogen-Manipulation of Photosynthesis for Hydrogen Generation}

Hydrogen $\left(\mathrm{H}_{2}\right)$ has a high calorific value of $\sim 122 \mathrm{~kJ} \cdot \mathrm{g}^{-1}$ and greater heating efficiency $\sim 2.75$-fold than hydrocarbon fuels [90]. The major route for its generation is from steam reforming, which accounts for $\sim 50 \%$ production through using syngas, natural gas, coal and waste biomass [91]. These processes operate at a high temperature (970-1100 $\left.{ }^{\circ} \mathrm{K}\right)$ and release a significant level of $\mathrm{CO}_{2}$ [92]. Hydrogen can also be generated from gasification (coal and biomass gasification), $\mathrm{H}_{2} \mathrm{O}$ electrolysis, partial oxidation, pyrolysis, and biological methods. Since combustion of $\mathrm{H}_{2}$ generates $\mathrm{H}_{2} \mathrm{O}$, it is viewed as a clean technology [93]. 
Approximately 120 million tonnes are produced annually from coal, oils, or chemicals, with China being the major player (22 million tonnes pa).

Hydrogen can also be produced from biological systems from photosynthesis, including photosynthetic bacteria (prokaryotic organisms) and microalgae (eukaryotic organisms), and from fermentation under certain conditions [94]. The usual gaseous product of photosynthesis in microalgae under aerobic conditions is $\mathrm{O}_{2}$. This is derived from the photolytic cleavage of $\mathrm{H}_{2} \mathrm{O}$ in the oxygen evolving complex [95]. This series of reactions involves 4 photons (excitons) causing a loss of 4 electrons from $2 \mathrm{H}_{2} \mathrm{O}$ molecules utilising the oxidation state of $\mathrm{Mn}$, which goes from overall $\mathrm{Mn}^{0}$ to $\mathrm{Mn}^{4+}$. The electrons from $\mathrm{H}_{2} \mathrm{O}$ feed into tyrosine in the subunit of photosystem II (PS11), whereby Photosystem II and Photosystem I are a series of electron carrying components that shuttle electrons on to acceptor $\mathrm{NADP}^{+}$. From PSII, electrons flow through a range of carrier molecules and onto the cytochrome $\mathrm{b}_{6} f$ complex (Figure 6). From there, electrons are passed onto PS1 via plastocyanin (PC) and ultimately the electrons pass onto the Fe-S protein, ferredoxin, and then on to $\mathrm{NADP}^{+}$, reducing it to NADPH. This reductant is used to drive many biosynthetic activities in the cells. However, under conditions of low $\mathrm{O}_{2}$, the electrons are channelled to an [Fe-Fe] hydrogenase enzyme, which utilises $\mathrm{H}^{+}$and the electron source to generate $\mathrm{H}_{2}$ [4].

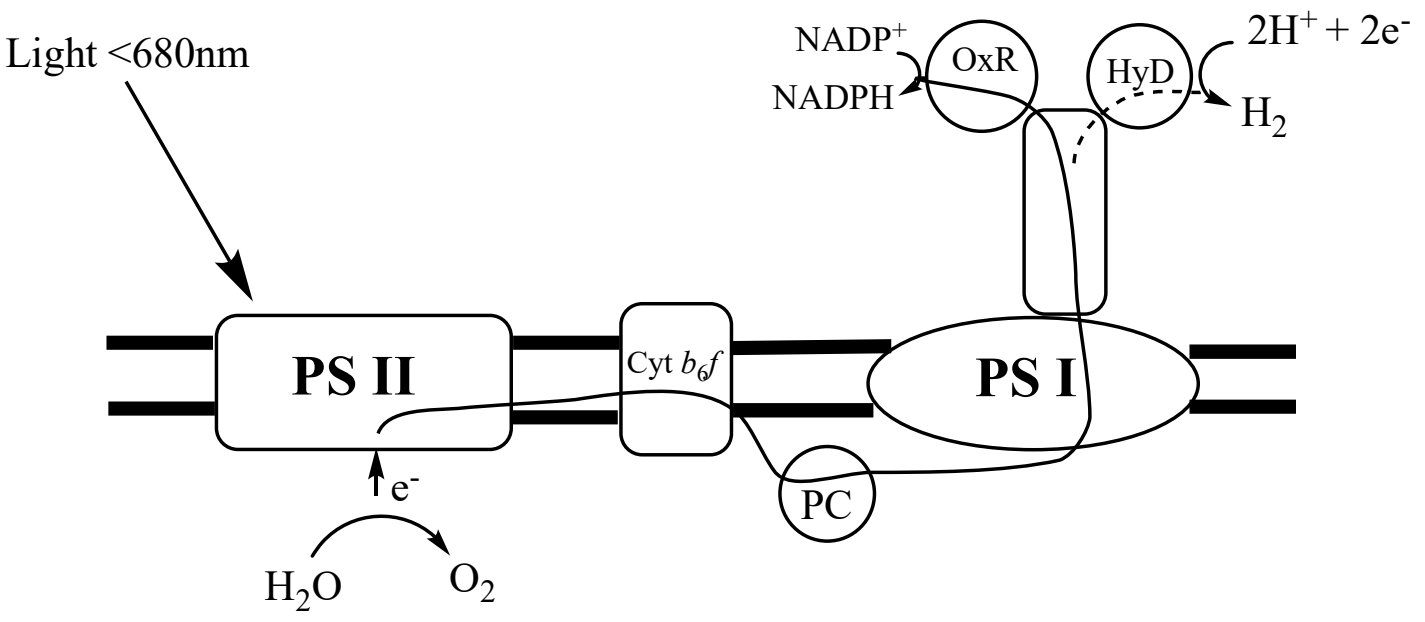

Figure 6. Electron flow in photosynthesis and in biohydrogen production.

The hydrogenase is $\mathrm{O}_{2}$ sensitive and is normally outcompeted when $\mathrm{O}_{2}$ is available. Since this mode of formation involves the electron transport chains of PS II and PS I, it is referred to as direct photolysis $\mathrm{H}_{2}$ production or photo-fermentation. During the light induced electron flow through, PSII and PSI $\mathrm{H}^{+}$are pumped from the cytochrome $\mathrm{b}_{6} f$ complex. These protons, together with those generated in photolysis, give rise to a $\mathrm{H}^{+}$ gradient and it is the net movement of these protons through the ATP-ase enzyme complex that gives rise to the formation of adenosine triphosphate (ATP) where the energy of movement of a proton (proton motive force) is just energetically sufficient to couple ADP (adenosine diphosphate) and Pi (inorganic phosphate) together to make ATP [96].

Indirect photolysis for $\mathrm{H}_{2}$ production involves the same electron transport chain as in direct photolysis [94] (Figure 6). However, there is no electron flow through PS II required (hence not directly light requiring) and the $\mathrm{O}_{2}$ is depleted by catabolism of fuel molecules in the tricarboxylic acid (TCA) and glycolytic pathways. The electrons are channelled from NADPH onto plastoquinone (PQ) and via the cytochrome $b_{6} f$ complex on to plastocyanin (PC). From here, the electrons flow as described above onto the hydrogenase to generate $\mathrm{H}_{2}$. Sulphur depletion promotes this route of electron flow by inhibiting the oxygenic pathway in PSII. Both direct and indirect pathways have been demonstrated in several microalgae, including Chlamydomonas, Chlorella, and Scenedesmus sp [94].

In recent years, the research focus has shifted onto firstly understanding the catalytic mechanism of hydrogenase and then to attempt genetic intervention to improve hydrogen 
production efficiency. Ten classes of hydrogenase are recognised and grouped into 3 families dependent type and arrange of metal ligands at the active site viz. [Fe-Fe]-hydrogenase, [Ni-Fe]-hydrogenase, and Fe-hydrogenase [97]. In microalgae, mainly [Fe-Fe]-hydrogenase are nuclear encoded but reside in the chloroplast and are monomeric 45-50 KDa proteins (where $1 \mathrm{Da}=1 \mathrm{~g} \mathrm{~mol}^{-1}$ for practical purposes) containing two Fe atoms at the catalytic site unit, linked via a sulphur bridge. Some variability in $\mathrm{O}_{2}$ sensitivity has been reported, with C. pyrenoidosa $\left(\mathrm{IC}_{50}\right.$ of $>21 \%$ ) having a significantly higher tolerance compared with other microalgae that were typically $<1 \%$. As commented upon earlier, pre-treatment of algal biomass to degrade cell walls enhances the fermentative $\mathrm{H}_{2}$ productivity up to $50-70 \%$. In addition, genetic manipulation of microalgae using genes from methanotrophs (methane utilising bacteria-such as Methylacidiphilum fumariolicum) to increase $\mathrm{O}_{2}$ tolerance and enhance biohydrogen production could be an approach [98].

It should be pointed out, however, that the generation of NADPH is of paramount significance for cell survival, since it is the ubiquitous molecule used in nearly all biosynthetic pathways. In that regard, there will always be a limitation on how much the diversion of electrons to hydrogen production can be tolerated in microalgae.

\subsection{Fast Pyrolysis}

Pyrolysis is a thermo-conversion technique performed at temperatures of around $500-600{ }^{\circ} \mathrm{C}$, in the absence of oxygen and at atmospheric pressure that has proved valuable for generating bio-oils from dry $(<5 \%$ moisture) lignocellulosic material with gas and biochar also being formed [99]. The proportions of these products vary depending on reactor conditions, with a higher heating rate and shorter residence times favouring the formation of higher levels of bio-oil [100]. For example, fast pyrolysis (FP) of Chlorella vulgaris and Dunaliella salina at $500{ }^{\circ} \mathrm{C}$ temperature gave $49.2 \%$ and $55.4 \%$ bio-oil yields, respectively [101]. The bio-oil product from fast pyrolysis of microalgae is characterized by a low oxygen content with a higher heating value of $29 \mathrm{MJ} \cdot \mathrm{kg}^{-1}$, a density of $1.16 \mathrm{~kg} \cdot \mathrm{L}^{-1}$, and a viscosity of $0.10 \mathrm{~Pa}$ s. These properties make it more suitable for fuel oil use than fast pyrolysis oils from lignocellulosic materials [102]. Although fast and intermediate pyrolysis of algae is possible at lab a scale level (providing valuable information on product generation e.g., [45]), it is, however, more limited in its application at the large scale required to generate bio-oils because of the cost implications in drying the material prior to thermal treatment.

\subsection{Hydrothermal Liquefaction}

An alternative thermal treatment to FP has evolved in recent years, in which water is used as the solvent for disruption. Therefore, the process can handle the high-water content of algae, although prior concentration of the biomass is still desirable. Hydrothermal liquefaction (HTL) is carried out in water at temperatures in the range of $280-370{ }^{\circ} \mathrm{C}$ and high pressures (10-25 MPa) (Figure 7) generating bio-oil as a main product along with the gaseous, aqueous, and solid phase by-products [103].

Three major steps have been identified: depolymerisation, decomposition, and recombination [104]. Macromolecules depolymerise into their constituent of building blocks (monomers or oligomers) and decompose via multi-pathway routes (e.g., cellulose degrades to glucose and undergoes dehydration to produce anhydro-sugars and the amino acid tyrosine degrades to generate aromatic hydrocarbons). The products generated are often highly reactive and recombine (polymerise) to generate further chemicals. A mass balance for Spirulina is given in Figure 8.

Since biomass is a complex mixture of macromolecules, the reaction chemistry and mechanisms of liquefaction are consequently also complex [6]. One of the major benefits of HTL is the consumption of only $10-15 \%$ of the energy in the feedstock, thus giving energy efficiencies in the range of $85-90 \%$. HTL can recover more than $70 \%$ of the feedstock carbon content which can be utilised for the carbon capture procedures. The bio-oil generated by 
HTL is also superior in quality to that generated from fast pyrolysis in most parameters, except for its $\mathrm{S}$ content and viscosity (Table 8) [103].

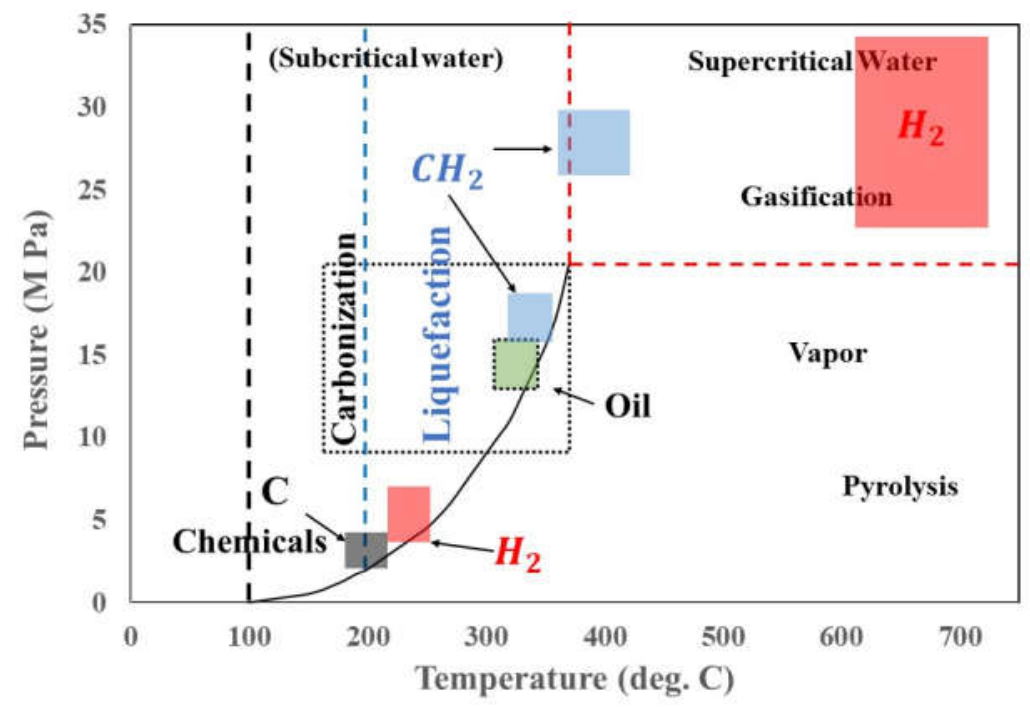

Figure 7. Principles of hydrothermal liquefaction. Modified from [103].

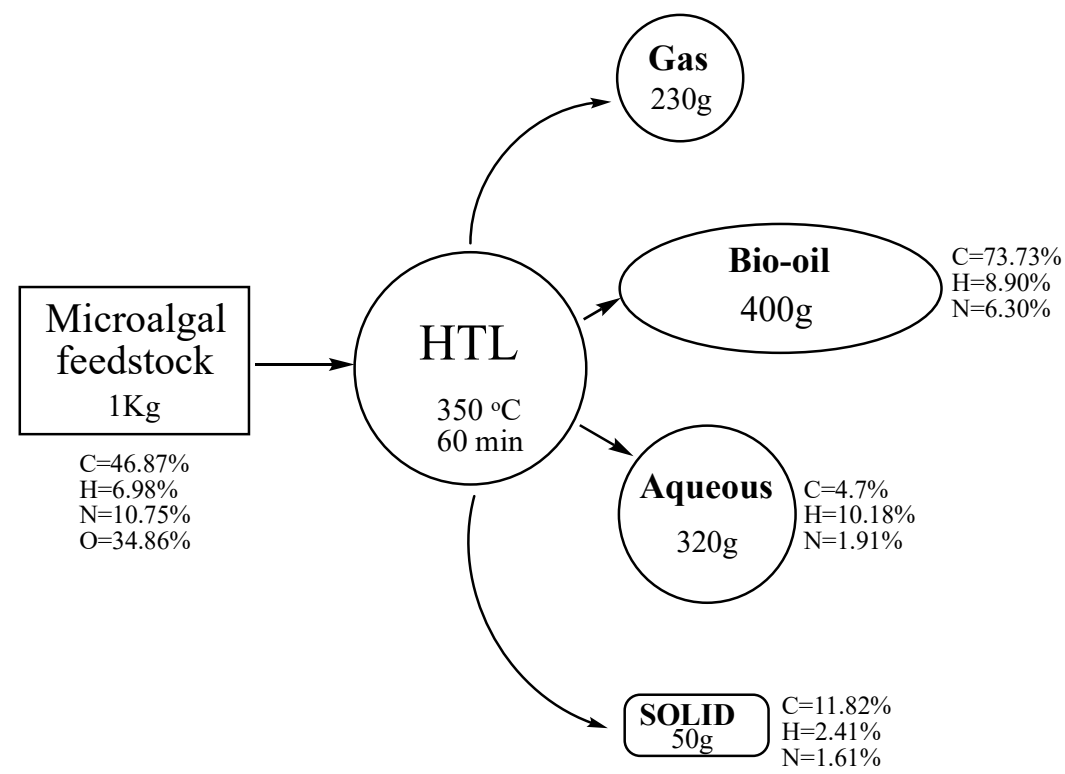

Figure 8. Mass balance of HTL using Spirulina modified from [85].

Table 8. Composition of bio-oil from pyrolysis and HTL. Modified from [103].

\begin{tabular}{ccc}
\hline Elemental Composition & HTL & Pyrolysis \\
\hline $\mathrm{C}(\mathrm{wt} \%)$ & 73 & 58 \\
$\mathrm{H}(\mathrm{wt} \%)$ & 8 & 6 \\
$\mathrm{O}(\mathrm{wt} \%)$ & 16 & 36 \\
$\mathrm{~S}(\mathrm{wt} \%)$ & $<45$ & 29 \\
Moisture & 5.1 & 24.8 \\
$\mathrm{HHV}\left(\mathrm{MJ} \mathrm{Kg}{ }^{-1}\right)$ & 35.7 & 22.6 \\
Viscosity $(\mathrm{cPs})$ & 15,000 & 59 \\
\hline
\end{tabular}

Improving the hydrocarbon contents in the bio-oil could be achieved through the use of nickel-based zeolites [105]. The oil yield from HTL is generally higher than from 
pyrolysis process, e.g., pyrolysis of Spirulina platensis at $500{ }^{\circ} \mathrm{C}$ was $29 \%$ whereas the biooil yield from HTL at $350{ }^{\circ} \mathrm{C}$ was $41 \%$ [106]. The typical energy content of microalgae is approximately $20 \mathrm{MJ} \cdot \mathrm{kg}^{-1}$, the heating value of the biocrude oil is close to that of petroleum oil [103]. Figure 8 shows mass and energy balance, and atomic balance of the hydrothermal liquefaction of Spirulina platensis where the bio-oil formed is the major product.

From HTL, the aqueous phase, nutrients, and $\mathrm{CO}_{2}$ generated can be recycled back for algae cultivation, thus reducing the shortfalls of the HTL process economy. Most studies have focused on batch HTL systems, but in order to make the process commercially viable a continuous system is desirable and the issues that need to be addressed have been reviewed [107]. The conventional HTL is unsuitable for high value product recovery but this could be overcome using a two-stage sequential hydrothermal liquefaction (SEQHTL) process which operates at reduced temperature and pressure to aid recovery of thermolabile products prior to generating bio-oil [108].

Microwave assisted HTL has also been examined [109], as has the application of HTL using macroalgae [110]. However, the economy of the process is still questionable due to the utilization of higher pressure conditions. Another current significant disadvantage of the HTL is the expensive of the reactors [111]. Reduction of cost of HTL processing of microalgae and use of catalysts to upgrade the biocrude oil quality are key targets for improvement.

\section{Algal Oils and Biodiesel Production}

Many microalgae are rich in triacylglycerols (oils) and the composition of the cell can vary from typically around $15 \%$ up to $60 \%$ by weight. Environmental stress can lead to the stimulation of oil production such as nutrient depletion, often involving nitrogen starvation. In general, freshwater algae tends to accumulate fatty acids in the C18 series, containing one to three double bonds in the acyl chain (18:1,18:2, and 18:3), whilst many from the marine environment accumulate long chain polyunsaturated fatty acids in the C20 series (e.g., 20:4 (AA), 20:5 (EPA), and 22:6 (DHA), see Figure 2). The basic pathway for oil synthesis involves the two-step acylation of glycerol 3-phosphate to yield phosphatidic acid (PA). The PA is then hydrolysed by a phosphatase to produce diacylglycerol (DAG), which then undergoes acylation at the sn-3 position to form triacylglycerol (TAG) (Figure 9) [112]. Additional reactions have been characterised in oilseeds that may also occur in algae that are involved in the synthesis of PUFAs and their subsequent incorporation into TAGs [113]. These include cross reactions between phospholipids (principally phosphatidylcholine, PC) and diacylglycerol catalysed by phospholipid diacylglycerol acyl transferase (PDAT), DAG-PC interchange (catalysing a reversible reaction between CDP-choline (a cytidine activated form of choline) and DAG), a transacylase that catalyses the formation of TAG from two molecules of DAG and acyl exchange that involves the high turnover of acyl groups at position sn-2 of PC with acyl groups in the acyl-CoA pool. In oil seeds, these reactions largely take place in the endoplasmic reticulum, although in algae evidence exists that these pathways may operate in the chloroplast [112].

Polyunsaturated fatty acids are undesirable components of fuel, as they are more prone to oxidation. Therefore, leading to the production of short chain aldehydes and ketones can have corrosive enhancing properties [68,70]. The oxidative stability of 18:2, $18: 3,20: 4$, and 22:6 is linearly related to the number of bis-allylic motifs and reveals that oxidisability increases approximately 2 -fold for each active bis-allylic methylene group, thus 22:6 is 5 times greater than 18:2 [75]. Production of high levels of monounsaturated acyl chains oils is therefore more desirable. This could be achieved by genetic manipulation and downregulation of the genes involved in PUFA synthesis. Interestingly, the enzymes involved in synthesising PUFAs (elongases and desaturases) are decreased in response to nitrogen limitation [71] and indeed stress appears to lower PUFA production in algae in general [70]. By contrast, low temperature appears to favour the synthesis of more highly unsaturated fatty acids in algae [68]. Therefore, a combination of genetic and environmental manipulation could result in the production of highly stable oils for use 
in high temperature environments, such as the combustion engine. The production of monounsaturated oils will be aided by the fact that several desaturases and elongases have been characterised from microalgae $[72,73]$ and their sequence data could hence be used to downregulate their activity, leading to lower PUFA content. This will be particularly important if marine strains of algae are going to be utilised for biodiesel production.

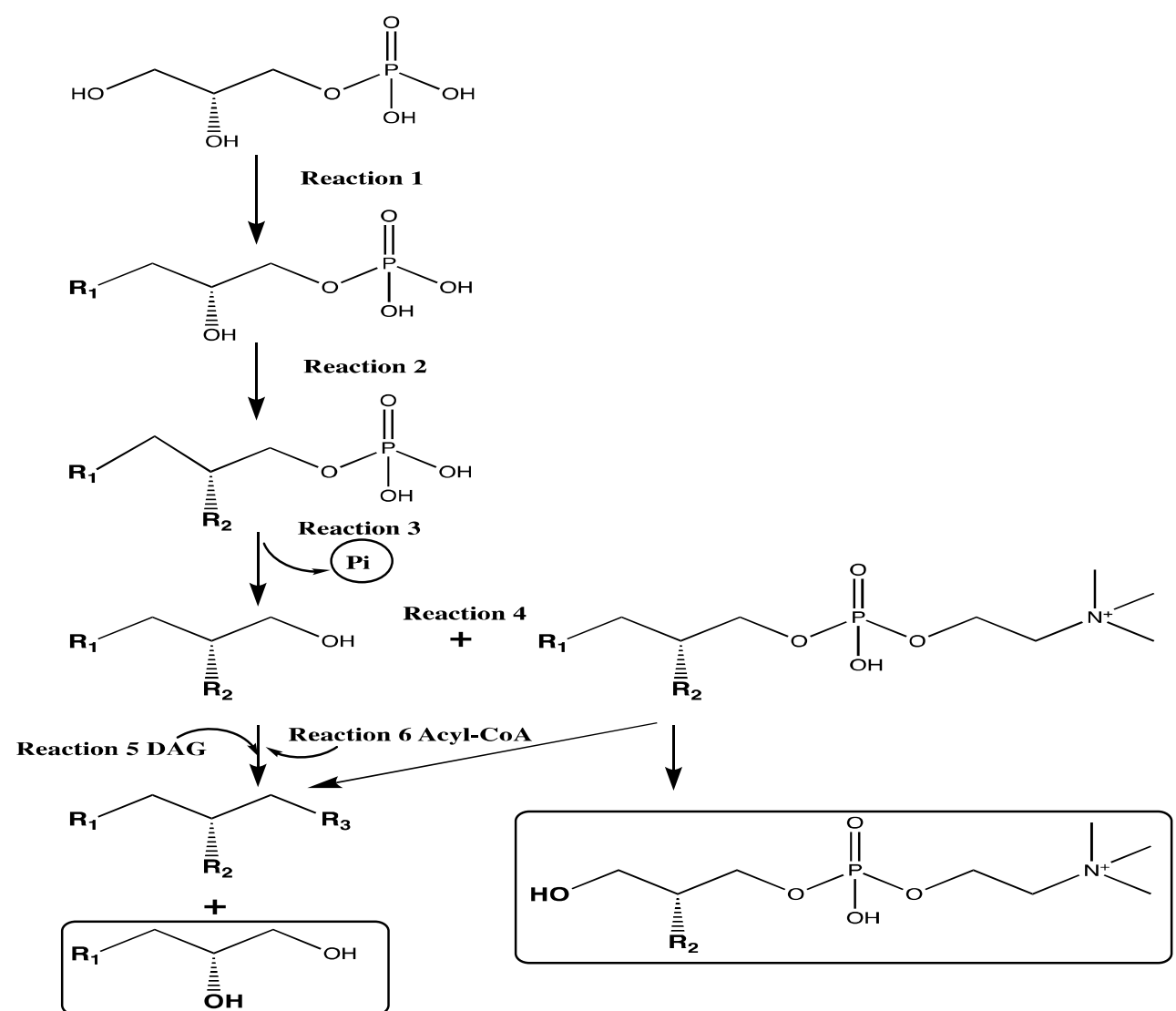

Figure 9. Biosynthesis of triacylglycerols in algae.

Reactions 1 and 2 are catalysed by separate acyltransferases using acyl-CoA substrates. Reaction 3 is the hydrolysis of the phosphate group by a phosphatase. Reaction 4 is catalysed by a phospholipid, diacylglycerol acyltransferase (PDAT), that results in the formation of triacylglycerol and lyso-phospholipid. Reaction 5 is a transacylase reaction and reaction 6 is catalysed by diacylglycerol acyltransferase (DGAT).

A visual overview of the process of biodiesel production is given is Figure 10.

Conventional diesel is composed of hydrocarbons (oxygen free) derived from the fractional distillation of crude petroleum. By contrast, the chemistry of algal oils is quite different and they are composed predominantly of triacylglycerols ( $95 \%)$, with small amounts of diacylglycerol and phospholipids ( 5\% combined) [114]. These natural products contain oxygen in the form of the ester bonds formed between the carboxylic acid of the fatty acid and the glycerol backbone [68].

Triacylglycerols have high boiling points and flash points and are generally converted to biodiesel for efficient use in combustion engines [68]. This involves the transesterification of the oil, usually with methanol, under anhydrous conditions in the presence of a catalyst (either a base such as $\mathrm{NaOH}$ or an acid such as $\mathrm{H}_{2} \mathrm{SO}_{4}$ ). This reaction forms a biphasic mixture with an upper methyl ester fraction and a lower glycerol phase.

Acid catalysts are minimally affected by unesterified fatty acids [115], so are often used when their level is $>1 \%$, and because they require a higher temperature and longer reaction times than alkaline catalysts, the process is more expensive [116]. The methyl ester can be blended with conventional diesel, typically in the range of 5-20\%. The generated fatty acid 
methyl esters (FAMEs) are then separated from the glycerol by-product, washed to remove traces of catalyst, dried, and used as biodiesel [69]. Algal biodiesel has been generated from various species with Botryococcus braunii, Nanocholoropsis oculata, and Dunaliella salina showing oil yields $>50 \%$ [117].

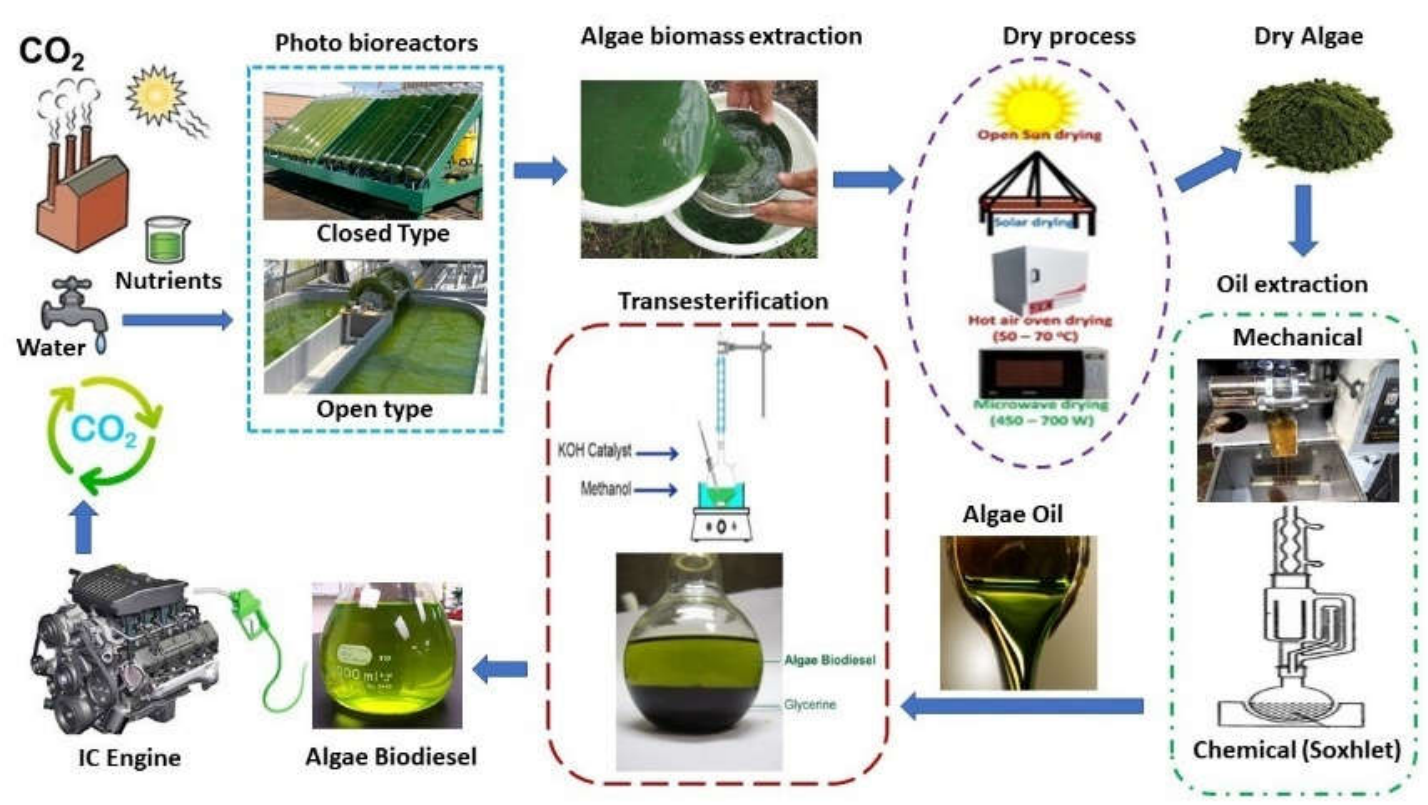

Figure 10. Flow diagram of biodiesel production.

In order to decrease the oxygen content in natural fatty acids and their derivatives technologies around hydrotreatment have been developed which aim to reduce the number of double bonds in the starting material and remove the $\mathrm{O}$ atoms in the carboxyl end of the molecule through decarboxylation/decarbonylation [118] (Figure 11).

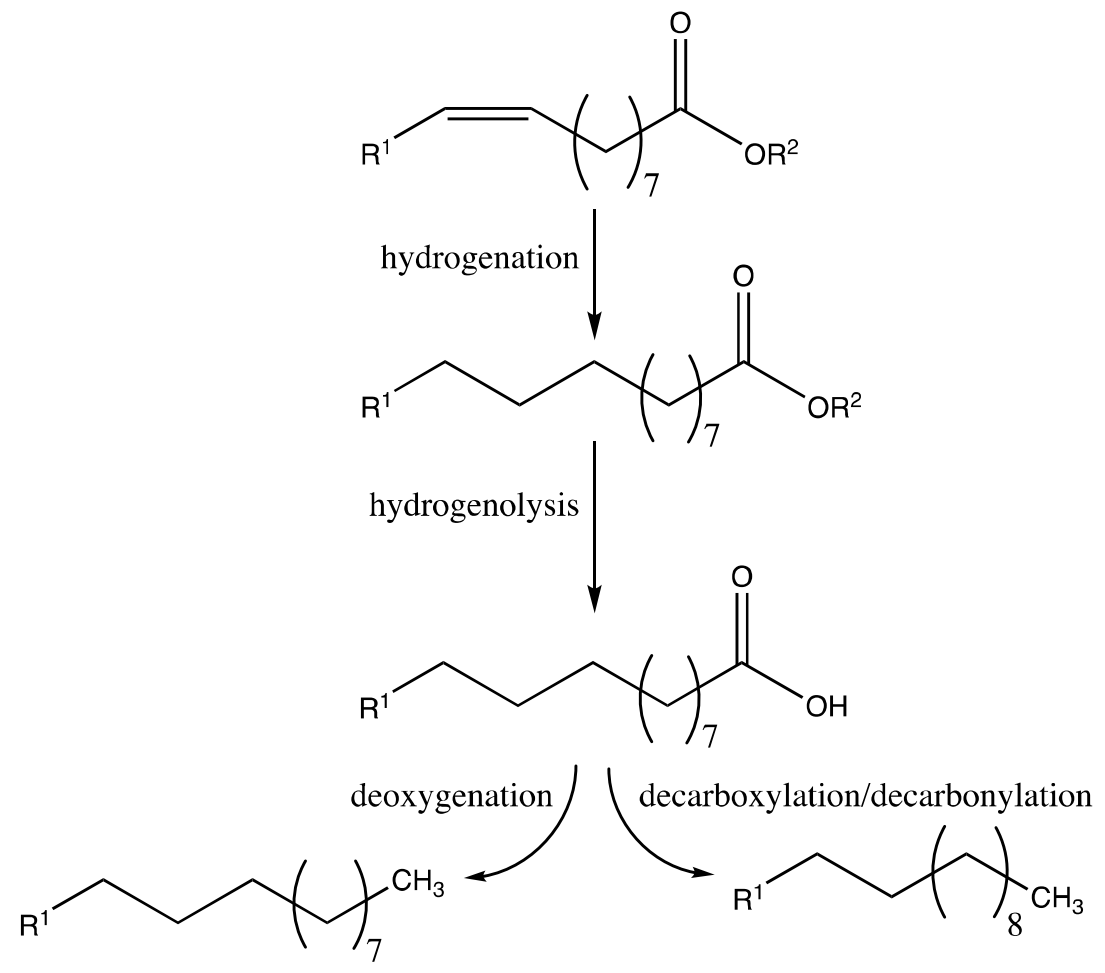

Figure 11. Hydrotreatment of oils to generate hydrocarbon-rich products. 


\subsection{Terpenoid 'Oils'}

Whilst the majority of oils produced in algae are triacylglycerols, the notable exception and the one that has been well researched is the 'oil' extracted from the Chlorophyte, Botryococcus braunii. This organism is the single largest contributor to crude oil and is a major component of oil shales. Instead of accumulating acyl-lipids, this species accumulates a range of linear and monocyclic terpenes, termed botryococcenes, to levels of up to $70 \%$ (Figure 12, structures (I) and (II)).<smiles>C=C[C@](C)(/C=C/[C@H](C)CC[C@H](C)C(=C)CC[C@H](C)C(=C)C)CC[C@@H](C)C(=C)CC[C@@H](C)C(=C)C</smiles>

(I)<smiles>C=C[C@](C)(/C=C/[C@H](C)CC/C=C(\C)CCC=C(C)C)CC/C=C(\C)CCC=C(C)C</smiles>

(II)

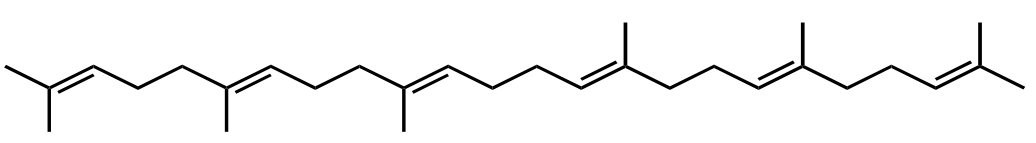

(III)

Figure 12. Structures two types of botryococcene (I) C34, (II) C30, and (III) squalene.

Squalene, a well-known precursor for plant sterols, is synthesised by squalene synthase, and this appears to also play a role in the production of botryococcenes, with which they share many structural similarities (Figure 9, structure III) [82]. However, in Botryococcus, botryococcenes consist of up to ten compounds $\left(\mathrm{C}_{\mathrm{n}} \mathrm{H}_{2 \mathrm{n}} ; \mathrm{n}=30-34\right)$, representing $25-40$ of its dry weight. Hydrocracking of the extracted 'oil' yielded $15 \%$ of an aviation fuel, $15 \%$ diesel fuel with $\sim 67 \%$ in the gasoline fraction [82]. The aviation fuel fraction met density and aromatic content specifications. Pre-treatment with hydrogen and prolonging the reaction time improved the yield of desired products. Hydro-processing requires a significant amount of hydrogen gas, although hydrothermal decarboxylation of fatty acids and their derivatives have been achieved using a platinum/carbon infiltrated $(\mathrm{Pt} / \mathrm{C})$ catalyst in water at $330^{\circ} \mathrm{C}$ and $370{ }^{\circ} \mathrm{C}$ without the need for added hydrogen [65].

\subsection{Alkenones}

To date, only a few members in the class of algae, Prymnesiophyceae (Haptophyta), have been shown to accumulate a rather unusual lipid, termed long-chain alkenones [119]. The chain length typical is in the range of $\mathrm{C}_{35}-\mathrm{C}_{41}$, which is around twice the chain length of typical acyl fatty acids. In addition, they contain trans double bonds that are spaced 5 carbons apart in contrast to the methylene interrupted systems in fatty acids, which also favour the cis orientation (Figure 2). The number of double bonds vary from 2-4 and the level of unsaturation is known to be linked to the water temperature, with higher temperatures favouring the synthesis of more saturated species. In Isochrysis galbana, under conditions aimed to stimulate lipid accumulation, the alga accumulated $29 \%$ of the dry weight as these products [120]. The high melting points $\left(\sim 70^{\circ} \mathrm{C}\right)$ make alkenones unsuitable for biodiesel production. Alkenones can be separated from fatty acids by a saponificationbased method [80]. Subsequent butenolysis of the alkenones (using 2-butene) generated a range of fuel jet range hydrocarbons principally, 2,9-undecane (43\%), 2-heptadecene (28\%) and 8-decen-2-one (12\%) as a mixture of cis and trans isomers (Figure 13) [80]. The tandem 
production of biodiesel from the fatty acids and jet fuel from the alkenones opens the possibility of a two-fuel generating system from a single algal feedstock.

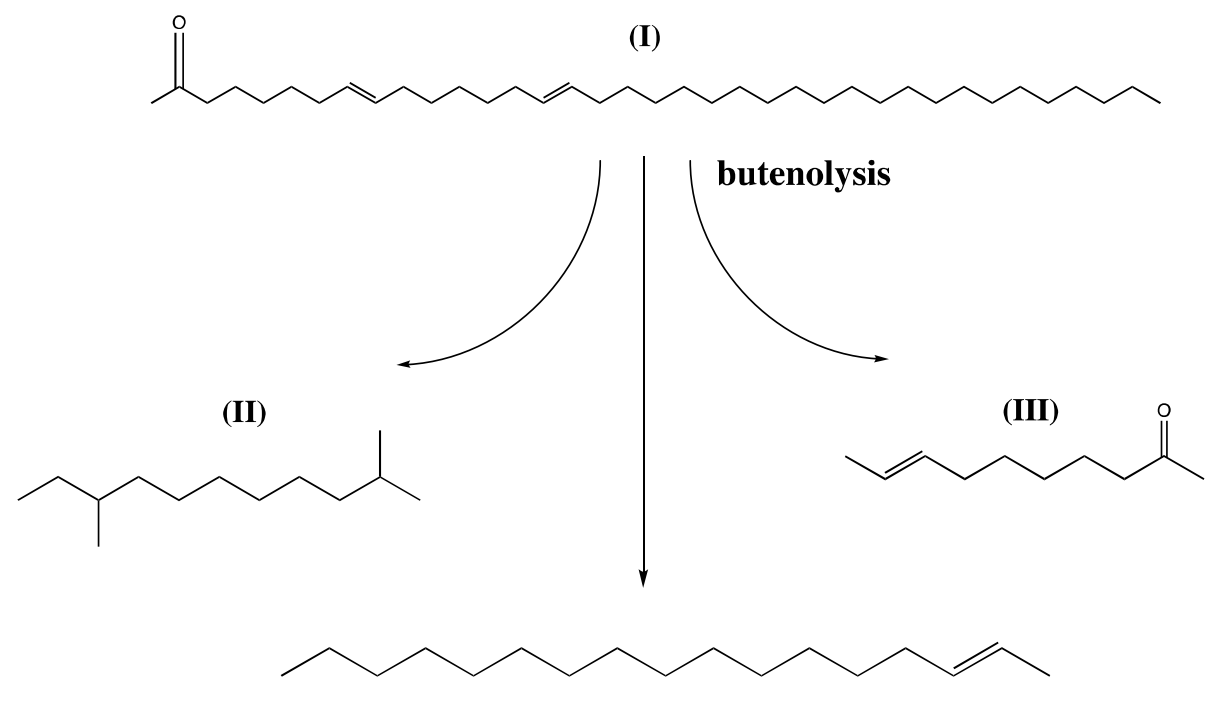

(IV)

Figure 13. Butenolysis of alkenones (I) generates a range of products, predominantly (II) 2, 9dimethyl undecane (III) 8-decen-2-one and (IV) 2-heptadene. Other products are generated but not illustrated.

\subsection{Biodiesel Fuel Characteristics}

The fuel properties of biodiesel from selected algal species are shown in Table 9. High fuel viscosity increases flow resistance and affects the fuel atomisation and combustion rate [121]. Both Dunaliella salina and Chlorella protothecoides have viscosities close to fossil fuel values, but the majority listed are significantly higher but within acceptable ranges. Flash points (the lowest temperature at which the liquid will evaporate enough to form a combustible concentration of gas) are also generally higher than the standard limit $\left(>52^{\circ} \mathrm{C}\right)$, making them less hazardous.

Table 9. Algae biodiesel fuel properties.

\begin{tabular}{|c|c|c|c|c|c|c|c|}
\hline Algal Species & $\begin{array}{c}\text { Viscosity (cst) } \\
\text { at } 40^{\circ} \mathrm{C}\end{array}$ & $\begin{array}{l}\text { Specific } \\
\text { Gravity }\end{array}$ & $\begin{array}{l}\text { Cloud Point } \\
\left({ }^{\circ} \mathrm{C}\right)\end{array}$ & $\begin{array}{l}\text { Pour Point } \\
\left({ }^{\circ} \mathrm{C}\right)\end{array}$ & $\begin{array}{c}\text { Flash Point } \\
\left({ }^{\circ} \mathrm{C}\right)\end{array}$ & $\begin{array}{l}\text { Cetane } \\
\text { Number }\end{array}$ & $\begin{array}{c}\text { Calorific Value } \\
\mathrm{MJ} \cdot \mathrm{kg}\end{array}$ \\
\hline Chlorella protothecoides & 2.8 & 0.867 & -27 & -11 & 124 & 52 & 40 \\
\hline Tolypothrix & 4.1 & 0.857 & 7.38 & 1.19 & - & 58 & - \\
\hline Dunaliella salina & 2.40 & 0.8513 & 0 & -6 & 129 & 50 & 34 \\
\hline Spirogyra & 4.4 & 0.884 & 3 & -7 & 78 & - & 13.62 \\
\hline Botryococcus braunii & 5.35 & 0.853 & - & - & 138 & - & 50 \\
\hline Chlorella vulgaris & 4.8 & 0.870 & 0 & -11 & 140 & 60 & 17.44 \\
\hline Cladophora & 3.8 & 0.892 & - & -12 & 110 & 60 & 17.44 \\
\hline Kirchneriella lunari & 4.15 & 0.882 & - & - & - & 51 & 41.50 \\
\hline Nannochloropsis oculata & 5.76 & 0.854 & 3.39 & -4 & 180 & 46 & 16.80 \\
\hline Entromorpha & 3.12 & 0.862 & -1 & -6 & 194 & 50 & 39.760 \\
\hline Stoechospermum marginatum & 4.84 & 0.890 & - & - & 128 & 63 & 42.05 \\
\hline Neochloris oleoabundans & 5.54 & 0.887 & -10 & -12 & 126 & 55 & 39.76 \\
\hline Crypthecodinium cohnii & 5.06 & 0.912 & 16.1 & & 95 & 46 & 39.86 \\
\hline Fossil diesel & 2.3 & 0.830 & - & - & 60 & 56 & 43.25 \\
\hline ASTM standard & $1.9-6.0$ & $0.86-0.9$ & - & - & $>52$ & $40 \mathrm{~min}$ & \\
\hline
\end{tabular}

Data adapted from [7,121-124].

They all show good ignition quality (indicated by a high cetane number), which is higher than diesel fuel and minimum standard limits, and good low temperature flow properties. The energy content is generally lower than conventional diesel, but Chlorella protothecoides, Stoechospermum marginatum, Neochloris oleoabundans, and Crypthecodinium cohnii algae biodiesel calorific values are close to fossil diesel (Table 9) [125]. 


\subsection{Algae Biodiesel Engine performance}

The engine brake thermal efficiency (BTE) refers to the conversion of fuel energy into useful work [126]. The BTE of microalgal biodiesels fuel varies with different algal species and engine operating parameters including exhaust gas recirculation (EGR) and additive, as summarised in Table 10. When compared to fossil diesel fuel, the BTE of pure, undiluted algal biodiesel (B100, where $100=100 \%$ ) obtained from Scenedesmus sp is reduced $[127,128]$ because of its higher viscosity, resulting in an inappropriate mixing of fuel and air, leading to late combustion during the expansion stroke. Botryococcus braunii derived algae biodiesel at 20\% level blended with fossil diesel (B20) shows a slight increment in the BTE [129]. However, biodiesels produced from Spirulina, Chlorella protothecoides, and Chlorella vulgaris algae show an increased BTE with B20 compared to diesel and B100 [130,131], thereby increasing the fuel atomisation and improving combustion efficiency [132].

Table 10. Engine characteristics of various algal biodiesels.

\begin{tabular}{|c|c|c|c|c|}
\hline Algae Types & \multirow[b]{2}{*}{$>$} & \multirow{2}{*}{$\begin{array}{l}\text { Performance } \\
\text { BTE increased by adding } \mathrm{TiO}_{2}-\mathrm{SiO}_{2} \\
\text { nano-particle as additive }\end{array}$} & \multicolumn{2}{|r|}{ Emissions } \\
\hline Botryococcus braunii & & & $>$ & $\begin{array}{l}\mathrm{CO}, \mathrm{HC} \text { and } \mathrm{NOx} \text { emissions decreased } \\
\mathrm{CO}_{2} \text { and smoke increased }\end{array}$ \\
\hline & & & $>$ & $\begin{array}{l}\mathrm{CO}_{2} \text { emission rose with increased blend\% } \\
\text { but reduced with raised engine load }\end{array}$ \\
\hline & $>$ & BTE reduced by $3 \%$ but increased with & $>$ & $\begin{array}{l}36 \% \text { reduction in } \mathrm{CO}_{2} \text { was observed with } \\
15 \% \text { addition of hydrogen }\end{array}$ \\
\hline Spirulina & $>$ & $\begin{array}{l}\text { addition of } 15 \% \text { hydrogen } \\
\text { BTE reduced with increases blend \% }\end{array}$ & $>$ & $\begin{array}{l}19 \% \text { reduction in } \mathrm{NOx} \text { was observed but } \\
\text { increased } 1.9 \% \text { with hydrogen addition }\end{array}$ \\
\hline & & & $>$ & $\begin{array}{l}\text { Smoke reduced by } 23 \% \text { whereas it increased } \\
\text { with hydrogen addition }\end{array}$ \\
\hline \multirow{3}{*}{ Chlorellaprotothecoides } & \multirow[b]{2}{*}{$>$} & \multirow{3}{*}{$\begin{array}{l}\text { BTE increased by } 5 \% \text { as compared } \\
\text { to diesel } \\
\text { BTE increased with EGR by } 6 \%\end{array}$} & $>$ & CO emission reduced by $23 \%$ for $\mathrm{B} 100$ and \\
\hline & & & $>$ & $\begin{array}{l}43 \% \text { with EGR } \\
62 \% \text { reduction in } \mathrm{CO}_{2} \text { was found with } \mathrm{B} 100\end{array}$ \\
\hline & $>$ & & $>$ & $\begin{array}{l}\text { HC decreased by } 48 \% \text { with EGR } \\
\text { NOx reduced by } 7.4 \% \text { with B100 and } 18 \% \\
\text { with EGR }\end{array}$ \\
\hline & & \multirow{4}{*}{$\begin{array}{l}\text { B20 shows higher BTE than other blends } \\
\text { BTE decreased with rise blend } \%\end{array}$} & $>$ & CO decreased by $20 \%$ for B20 \\
\hline & $>$ & & $>$ & Average $1.5 \% \mathrm{CO}_{2}$ decreased for all blends \\
\hline Chlorella vulgaris & $>$ & & $>$ & HC emission was found to be lower by $3 \%$ \\
\hline & & & $>$ & $\begin{array}{l}\text { No significant changes was observed in } \\
\text { NOx emissions }\end{array}$ \\
\hline & $>$ & B25 and B50 show $0.3 \%$ and $0.5 \%$ lower & $>$ & $\begin{array}{l}\text { CO decreased by } 23 \% \text { and } 40 \% \text { for B25 } \\
\text { and B } 50\end{array}$ \\
\hline Scenedesmus sp. & & BTE than diesel & $>$ & $\begin{array}{l}\text { Average reduction in NOx was noticed } \\
\text { by } 15 \%\end{array}$ \\
\hline
\end{tabular}

Data combined from several sources (see [127,128,130-132].

\subsection{Algae Biodiesel Engine Emissions}

A list of engine BTE performance characteristics and emissions for 5 algal species is presented in Table 10. In terms of engine out emissions, algal biodiesel generally shows lower emissions of $\mathrm{CO}$, hydrocarbons (HC), and nitrous oxides (NOx) compared to fossil diesel fuel, although this is species specific (see Table 10 for details). Carbon dioxide $\left(\mathrm{CO}_{2}\right)$ is the by-product of full combustion and is essential for the creation of ozone [126]. The rate at which $\mathrm{CO}_{2}$ is produced by an engine is determined by several parameters, including engine speed, combustion chamber geometry, air velocity, and fuel properties. $\mathrm{CO}_{2}$ emission are generally found to be lower than diesel fuel with all types of algae biodiesel [127]. With the addition of $15 \%$ hydrogen, Spirulina biodiesel shows a $36 \%$ reduction in $\mathrm{CO}_{2}$, whereas, it is further reduced by $62 \%$ with Chlorella protothecoides-derived biodiesel with EGR dilution [130]. Chlorella vulgaris, Scenedesmus sp, and Botryococcus braunii, algal-derived biodiesels, all show lower $\mathrm{CO}, \mathrm{HC}$, and NOx emissions and smoke as 
compared to fossil diesel [132] (Table 10). Overall, the fuel characteristics of algal biodiesel are highly favourable for use as an engine fuel.

\subsection{Algal Biodiesel Cost}

The current cost of petroleum oil is $\sim \$ 100$ per barrel (equivalent to $\$ 0.62$ per $\mathrm{L}$ ). In contrast, algal biofuel is $\sim \$ 8.72$ per L. Thus, in order for it to effectively compete, the cost reduction will need to be lowered by an order of magnitude. Recently, developments by ExxonMobil in generating a Nanochloropsis gaditana strain engineered with a double oil content (up from $20 \%$ to $40 \%$ ) coupled with improved lipid extraction, using impinging jet mixers to introduce turbulent solvent mixing with algae without recourse to prior lipid extraction [133], may aid in reducing costs.

\section{Integrated Biorefinery Approaches}

It is evident from the analysis of individual technologies cited above that fuel production, e.g., bioethanol, biohydrogen, bio-oil, or biodiesel, are uneconomical on their own because of the costs associated with nutrient supply, harvesting, and processing. Therefore, integrated approaches whereby multiple products (co-products) and water/nutrient re-cycling take place is going to be essential to improve efficiency and make the process economically viable. Indeed, high value products extracted from algae are currently economical and may be an underlaying driver for the generation of subsidised fuel in the future, i.e., the fuel is a by-product of high value chemical production. The major hurdle faced by the microalgae cultivation process is the limited bio-mass concentration in the mature culture limited to around $3 \mathrm{~g} \cdot \mathrm{L}^{-1}$ compared to $30-100 \mathrm{~g} \cdot \mathrm{L}^{-1}$ biomass concentration of heterotrophic bacteria [134]. While many schemes exist for the flow of potential products from algae, few actually outline an integrated scheme defining the technologies required at each step. Here, we propose a possible biorefinery scheme, based firstly on the extraction of a high value product (e.g., pigments, FFA etc.) (Figure 14). The residue left behind is then used for fuel production and is subjected to $A D$, which generates a liquid digestate from which nutrients can be stripped using struvite precipitation and recycled back into the growth medium.

During AD, biogas ( $70 \%$ methane) is generated and can be used as a source of $\mathrm{CH}_{4}$, while the residual $\mathrm{CO}_{2}$ is recycled for algal growth. The solid digestate is then subjected to HTL, producing a mixture of bio-oil, char, gases and aqueous, with the latter being rich in nutrients and recyclable. The char can be used as a soil ameliorator and the $\mathrm{CH}_{4}$ recovered from the gas and $\mathrm{CO}_{2}$ recycled as described above. The bio-oil can be used as a heating fuel and or a chemical stream.

Hydrothermally produced bio-oils show a lower oxygen content (16\%) than that produced via fast pyrolysis (36\%) and a higher heating value $\left(35.7 \mathrm{MJ} \cdot \mathrm{kg}^{-1}\right.$ c.f. $22.6 \mathrm{MJ} \cdot \mathrm{kg}^{-1}$ ) and higher viscosity $(15,000 \mathrm{cPs}$ compared to $9 \mathrm{cPs}$, where $\mathrm{cP}$ is in centipoise units of $1 \mathrm{~cm}^{-1} \cdot \mathrm{g} \cdot \mathrm{s}^{-1}$ and water at $20^{\circ} \mathrm{C}$ is $1 \mathrm{cP}$ ) [103]. The main product is the high value chemical, and the co-products are biochar, biogas, bio-oil, and nutrients. The sequential extraction of valuable compounds from microalgae makes the biorefinery proposition appealing for waste minimisation, revenue diversification, and complete feedstock utilisation. Detailed techno-economic, environmental, and lifecycle assessment would be required for this biorefinery protocol. In a recent techno-economic evaluation of an algal biorefinery based on extraction of oil for biodiesel followed by sequential extraction of high value products concluded that, with the existing downstream-processing techniques, the microalgae bio-refinery approach is not sustainable and feasible [135]. 


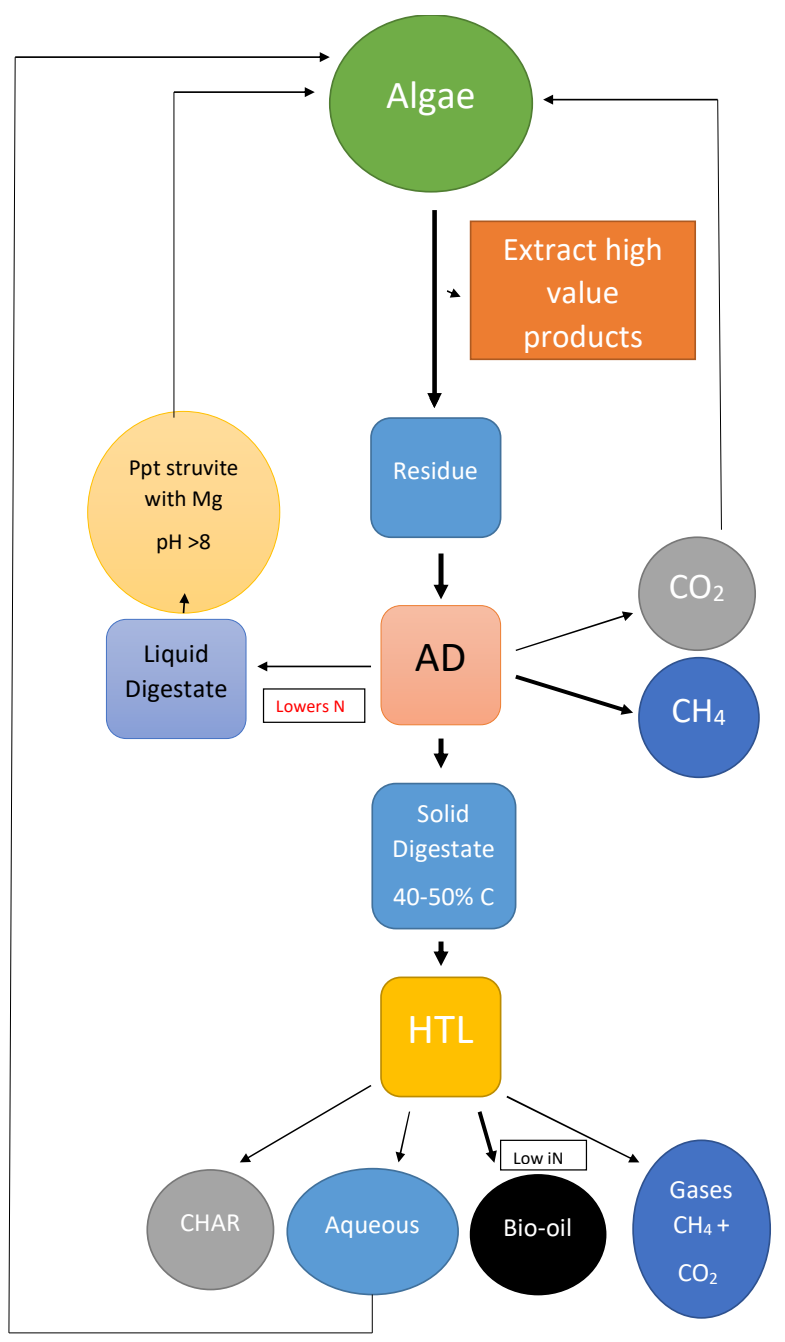

Figure 14. A biorefinery approach to valorising algal biomass post-high value product extraction. (Wahab M and Griffiths G, unpublished).

The possibility also exists to utilize AD digestates of seaweeds as sources of nutrients for microalgal culture to reduce costs. Macroalgae biomass is suitable for anaerobic digestion (AD). However, in order to promote the sustainability of an algal biorefinery, the valorisation of seaweed digestate, as a secondary resource for energy and nutrient recovery, is required to increase yields and co-products that would improve the overall efficiency of the system. Recently, we have shown that anaerobic digestion (AD) and dark fermentation (DF) of seaweeds (Laminaria, Ascophyllum, and Chaetomorpha) is an alternative 'green' pre-treatment to improved subsequent bio-oil quality following pyrolysis (Wahab, M et al., Energy Conversion and Management, in press). The bio-oil was richer in hydrocarbons (including toluene) and lower in anhydro-sugars than the raw seaweed feedstock derived bio-oil, and therefore more similar to petroleum-based profiles. The liquid digestate was also able to support the growth of Chlorella sorokiniana at levels equivalent to or better than standard TAP medium, with the triacylglycerols being enriched in monounsaturated fatty acids suitable for biodiesel generation. Overall, the results indicate that using AD of seaweed solid digestates can generate improvements in the quality of products obtained by pyrolysis and the liquid digestate can positively influence the growth of microalgae and its products.

In another algal biorefinery scenario, dilute acid pre-treatment was shown to improve the utilisation of algal biomass by hydrolysing carbohydrates into fermentable sugars, making the lipids and proteins easier to extract [136]. Following solid-liquid separation, 
the ethanol generated and the remaining lipids were sequentially recovered from the fermentation broth by thermal treatment and solvent extraction. The techno-economic analysis indicated a fuel reduction cost by $\$ 0.95$ per gallon gasoline equivalent (GGE), which is a $9 \%$ reduction compared to the previous biorefinery scenario.

\section{Conclusions}

Macroalgae ('seaweeds') are predominantly grown for human consumption and for high value extractives. In terms of biofuel, the most promising processes are anaerobic digestion for biomethane production and fermentation for bioethanol. Currently, both processes are limited by the slow rate of degradation of the complex polysaccharide cell walls. Research effort in this area should therefore be focused on producing a cocktail of cell wall degrading enzymes (predominantly hydrolytic in nature) and have specificity for the algae being digested. This will involve undertaking detailed biochemical studies of the cell wall degrading enzymes, characterizing them, and using genetic engineering techniques to overexpress and bulk produce them. Since most macroalgae are harvested form coastal waters, nutrient costs are not generally a factor and indeed in areas where there is extensive run off of fertilisers from agricultural land, high productivity has been observed. Starchrich microalgae are also suitable for bioethanol production and are amenable to genetic manipulation to regulate starch levels. Hydrothermal liquefaction of both micro- and macro-algae also has potential, though existing reactors are expensive as are the costs associated generating the high pressures required. The bio-oil formed is unstable and requires upgrading, bringing additional costs. In desert areas, the potential is there to utilise the sun's rays as a heat source to achieve liquefaction, thereby reducing costs, and should be considered for further development.

Biohydrogen is less appealing as an energy source from algae, due to the limited nature of its production imposed by the necessity of the organisms to generate high levels of ATP from photosynthesis for growth.

Microalgae, unlike macroalgae, are often characterised by a high lipid content and are therefore suited to the production of biodiesel. In order to compete with petroleum, cost reductions of an order of magnitude need to be made. Economic assessments for growing microalgae favour the open raceway system and using non-potable water sources, such as seawater, brackish water, or wastewater, particularly those from food industries which contain nutrients and would reduce production costs. Improving the harvesting of microalgae through more efficient flocculation methods would also help reduce dewatering costs. Such costs could also be reduced further by using more efficient lipid extraction systems such as jet mixers.

In the search to find locations for where to locate large scale production sites and not compete with arable land or disrupt urban populations, deserts have an appeal. However, they are not without their challenges such as hostile environment (e.g., sandstorms), extreme temperatures, little or no nearby infrastructure, or giant sand dunes (e.g., Namib desert). The identification of naturally occurring high lipid strains that can have significant tolerance to temperature changes and changes in salinity would be favourable and could be identified through extensive species profiling in geographical regions of interest. Genetic engineering of microalgae to obtain these traits is possible (ExxonMobil have generated a high oil yielding Nanochloropsis (increased from $20 \%$ to $40 \%$ oil content, see webpage references), though public acceptance of the introduction of such organisms into the wider environment will likely be met by some resistance.

Overall, the commercial challenges for algal biofuel production remain but are not insurmountable. It is likely that the incremental improvement in growing, harvesting, extraction, and biomass conversion technologies will reach a favourable tipping point and this time frame will be accelerated as the inevitable cost of petroleum, either directly or indirectly, through taxation/carbon trading starts taking effect. 


\section{Webpage Links}

${ }^{\mathrm{P}}$ Food and Agriculture Organization of the United Nations, Rome, 2018. 124. Ferdouse F, Lovstad Holdt, S, Smith, R, Murua and Yang Z. https:/ / www.proquest.com/ openview /63a9872d1ea30c63f92d5d8acfcd6e35/1?pq-origsite=gscholar\&cbl=237312 (accessed on 31 August 2021).

II Global ethanol production by country or region https:/ / afdc.energy.gov (accessed on 19 September 2021).

* BARD Algae claim 8,571,428 gallons of algae oil per acre https:/ / www.greentechmedia. com/articles/read/8571428-gallons-of-algae-oil-per-acre (accessed on 28 August 2021).

${ }^{\dagger}$ Flynn Kevin, Swansea University, https:/ / www-2018.swansea.ac.uk/press-office/newsarchive/2017/algalbiofuelproductionisneitherenvironmentallynorcommerciallysustainable.php (accessed on 31 August 2021).

ExxonMobil generate high oil yielding Nanochloropsis gaditana using genetic manipulation. https://corporate.exxonmobil.com/Energy-and-innovation/Advanced-biofuels/ Advanced-biofuels-and-algae-research\#Biofuelsresearchportfolio (accessed on 29 August 2021).

Author Contributions: Conceptualization, G.G.; methodology, G.G., V.S., A.K.H. and G.D.; software, G.G., V.S.; validation, G.G., V.S. and A.K.H.; formal analysis, G.G., V.S. and A.K.H.; investigation; resources, G.G., A.K.H. and G.D.; data curation, G.G. and V.S.; writing-original draft preparation, G.G., V.S. and A.K.H.; writing-review and editing, G.G. and V.S.; visualization, G.G. and V.S.; supervision, G.G., A.K.H. and G.D.; project administration, A.K.H.; funding acquisition, A.K.H., G.D., G.G. All authors have read and agreed to the published version of the manuscript.

Funding: This work was funded by the UKIERI project (Grant number DST-UKIERI 18-19-04): Waste to Energy-Low Temperature Combustion of Sustainable Green Fuels.

Institutional Review Board Statement: Not applicable.

Informed Consent Statement: Not applicable.

Data Availability Statement: Data are in the public domain.

Acknowledgments: This study was funded by the DST-UKIERI project (Grant Number: DST-UKIERI 18-19-04): Waste to Energy_Low-Temperature Combustion of Sustainable Green Fuels.

Conflicts of Interest: The authors declare no conflict of interest.

\section{List of Abbreviations}

$\begin{array}{ll}\text { AA } & \text { arachidonic acid } \\ \text { AD } & \text { Anaerobic digestion } \\ \text { Asx } & \text { astaxanthin } \\ \text { B100 } & 100 \% \text { biodiesel } \\ \text { BMP } & \text { biomethane potential } \\ \text { BTE } & \text { Brake thermal efficiency } \\ \text { Cyt } b_{6} f & \text { cytochrome } b_{6} f \text { complex } \\ \text { DHA } & \text { docosahexaenoic acid } \\ \text { DAG } & \text { diacylglycerol } \\ \text { EGR } & \text { exhaust gas re-circulation } \\ \text { EPA } & \text { eicosapentaenoic acid } \\ \text { FFA } & \text { free fatty acid } \\ \text { FP } & \text { fast pyrolysis } \\ \text { FAME } & \text { fatty acid methyl ester } \\ \text { GM } & \text { genetic modification } \\ \text { HTL } & \text { hydrothermal liquefaction } \\ \text { HyD } & \text { hydrogenase } \\ \text { LCFA } & \text { long chain fatty acid } \\ \text { NADP } & \text { nicotinamide adenine dinucleotide phosphate } \\ \text { OxR } & \text { oxidoreductase }\end{array}$




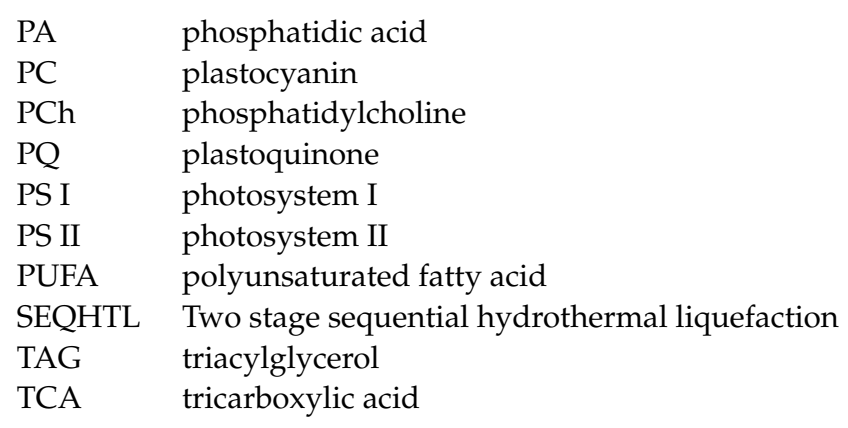

\section{References}

1. Slade, R.; Bauen, A. Micro-algae cultivation for biofuels: Cost, energy balance, environmental impacts and future prospects. Biomass Bioenergy 2013, 53, 29-38. [CrossRef]

2. Fasaei, F.; Bitter, J.H.; Slegers, P.M.; Van Boxtel, A.J.B. Techno-economic evaluation of microalgae harvesting and dewatering systems. Algal Res.-Biomass Biofuels Bioprod. 2018, 31, 347-362. [CrossRef]

3. Ramachandra, T.V.; Hebbale, D. Bioethanol from macroalgae: Prospects and challenges. Renew. Sustain. Energy Rev. 2020, 117, 109479. [CrossRef]

4. Manoyana, J.; Gabrielyana, L.; Kozelb, N.; Trchouniana, A. Regulation of biohydrogen production by protonophores in novel green microalgae Parachlorella kessleri. J. Photochem. Photobiol. B Biol. 2019, 199, 111597. [CrossRef] [PubMed]

5. Milledge, J.J.; Nielsen, B.V.; Maneein, S.; Harvey, P.J. A Brief Review of Anaerobic Digestion of Algae for Bioenergy. Energies 2019, 12, 1166. [CrossRef]

6. Paula, T.; Sinharoy, A.; Baskaran, D.; Kannan, P.; Pugazhenthi, G.; Lens, P.N.L. Bio-oil production from oleaginous microorganisms using hydrothermal liquefaction: A biorefinery approach. Crit. Rev. Environ. Sci. Technol. 2020. [CrossRef]

7. Katam, G.B.; Murthy, M.; Warkhade, G.S. Review on algae for biodiesel fuel production, its characteristics comparison with other and their impact on performance, combustion and emissions of diesel engine. World J. Eng. 2017, 14, 127-138. [CrossRef]

8. Bridgwater, A.V. Review of fast pyrolysis of biomass and product upgrading. Biomass Bioenergy 2012, 38, 68-94. [CrossRef]

9. Manoylov, K.M. Taxonomic identification of algae (morphological and molecular): Species concepts, methodologies, and their implications for ecological bioassessment. J. Phycol. 2014, 50, 409-424. [CrossRef]

10. Leliaert, F.; Verbruggen, H.; Vanormelingen, P.; Steen, F.; Lopez-Bautista, L.M.; Zuccarello, G.C.; De Clerck, O. DNA-based species delimitation in algae. Eur. J. Phycol. 2014, 49, 179-196. [CrossRef]

11. Brodie, J.; Chan, C.X.; De Clerck, O.; Cock, J.M.; Coelho, S.M.; Gachon, C.; Grossman, A.R.; Mock, T.; Raven, J.A.; Smith, A.G.; et al. The Algal Revolution. Trends Plant Sci. 2017, 22, 726-738. [CrossRef]

12. Bringloe, T.T.; Samuel, S.; Rachael, M.W.; Christophe, V.; Hiroshi, K.; Olivier, D.C.; Mark, J.C.; Susana, M. Phylogeny and Evolution of the Brown Algae. Crit. Rev. Plant Sci. 2020, 39, 281-321. [CrossRef]

13. Pereira, L.; Valado, A. The Seaweed Diet in Prevention and Treatment of the Neurodegenerative Diseases. Mar. Drugs 2021, 19, 128. [CrossRef]

14. Mularczyk, M.; Michalak, I.; Marycz, K. Astaxanthin and other Nutrients from Haematococcus pluvialis-Multifunctional Applications. Mar. Drugs 2020, 18, 459. [CrossRef] [PubMed]

15. Bosnjakovic, M.; Sinaga, N. The Perspective of Large-Scale Production of Algae Biodiesel. Appl. Sci. 2020, 10, 8181. [CrossRef]

16. Zheng, Y.; Jin, R.; Zhang, X.; Wang, Q.; Wu, J. The considerable environmental benefits of seaweed aquaculture in China. Stoch. Environ. Res. Risk Assess. 2019, 33, 1203-1221. [CrossRef]

17. Kim, J.K.; Charles, Y.; Eun, K.H.; Miseon, P.; Youngdae, K. Seaweed aquaculture: Cultivation technologies, challenges and its ecosystem services. Algae 2017, 32, 1-13. [CrossRef]

18. Zuniga-Jara, S.; Contreras, C. An economic valuation of the commercial cultivation ofAgarophyton chilensisin northern Chile. J. Appl. Phycol. 2020, 32, 3233-3242. [CrossRef]

19. Mantri, V.A.; Ganesan, M.; Gupta, V.; Krishnan, P.; Siddhanta, A.K. An overview on agarophyte trade in India and need for policy interventions. J. Appl. Phycol. 2019, 31, 3011-3023. [CrossRef]

20. Buschmann, A.H.; Camus, C.; Infante, J.; Neori, A.; Israel, Á.; Hernández-González, M.C.; Pereda, S.V.; Gomez-Pinchetti, J.L.; Golberg, A.; Tadmor-Shalev, N.; et al. Seaweed production: Overview of the global state of exploitation, farming and emerging research activity. Eur. J. Phycol. 2017, 52, 391-406. [CrossRef]

21. Rebours, C.; Marinho-Soriano, E.; Zertuche-González, A.J.; Hayashi, L.; Vásquez, J.A.; Paul, K. Seaweeds: An opportunity for wealth and sustainable livelihood for coastal communities. J. Appl. Phycol. 2014, 26, 1939-1951. [CrossRef] [PubMed]

22. Chopin, T.; Tacon, A.G.J. Importance of Seaweeds and Extractive Species in Global Aquaculture Production. Rev. Fish. Sci. Aquac. 2021, 29, 139-148. [CrossRef]

23. Liang, Y.N.; Sarkany, N.; Cui, Y. Biomass and lipid productivities of Chlorella vulgaris under autotrophic, heterotrophic and mixotrophic growth conditions. Biotechnol. Lett. 2009, 31, 1043-1049. [CrossRef]

24. Zheng, Y.; Chi, Z.; Lucker, B.; Chen, S. Two-stage heterotrophic and phototrophic culture strategy for algal biomass and lipid production. Bioresour. Technol. 2012, 103, 484-488. [CrossRef] [PubMed] 
25. Tassoni, A.; Awad, N.; Griffiths, G. Effect of ornithine decarboxylase and norspermidine in modulating cell division in the green alga Chlamydomonas reinhardtii. Plant Physiol. Biochem. 2018, 123, 125-131. [CrossRef] [PubMed]

26. Awad, N.; Vega-Estevez, S.; Griffiths, G. Salicylic acid and aspirin stimulate growth of Chlamydomonas and inhibit lipoxygenase and chloroplast desaturase pathways. Plant Physiol. Biochem. 2020, 149, 256-265. [CrossRef] [PubMed]

27. Sánchez-Saavedra, M.; Sauceda-Carvajal, D.; Castro-Ochoa, F.Y.; Molina-Cárdenas, C.A. The Use of Light Spectra to Improve the Growth and Lipid Content of Chlorella vulgaris for Biofuels Production. Bioenergy Res. 2020, 13, 487-498. [CrossRef]

28. Dahlin, L.R.; Gerritsen, A.T.; Henard, C.A.; Wychen, A.V.; Linger, J.G. Development of a high-productivity, halophilic, thermotolerant microalga Picochlorum renovo. Commun. Biol. 2019, 2, 388-391. [CrossRef]

29. Barros, A.; Pereira, H.; Campos, J.; Marques, A.; Varela, J.; Silva, J. Heterotrophy as a tool to overcome the long and costly autotrophic scale-up process for large scale production of microalgae. Sci. Rep. 2019, 9, 13935. [CrossRef] [PubMed]

30. Fabris, M.; Abbriano, R.M.; Pernice, M.; Sutherland, D.L.; Commault, A.S.; Hall, C.C.; Labeeuw, L.; McCauley, J.I.; Kuzhiuparambil, U.; Ray, P.; et al. Emerging Technologies in Algal Biotechnology: Toward the Establishment of a Sustainable, Algae-Based Bioeconomy. Front. Plant Sci. 2020, 11, 279. [CrossRef]

31. Pacheco, D.; Rocha, A.C.; Pereira, L.; Verdelhos, T. Microalgae Water Bioremediation: Trends and Hot Topics. Appl. Sci. 2020, 10, 1886. [CrossRef]

32. Craggs, R.J.; Heubeck, S.; Lundquist, T.J.; Benemann, J.R. Algal biofuels from wastewater treatment high rate algal ponds. Water Sci. Technol. 2011, 63, 660-665. [CrossRef]

33. Cheng, D.; Li, X.; Yuan, Y.; Zhao, Q. Kinetic model for effects of simulated flue gas onto growth profiles of Chlorella sp. AE10 and Chlorella sp. Cv. Biotechnol. Appl. Biochem. 2020, 67, 783-789. [CrossRef]

34. Veronesi, D.; D'Imporzano, G.; Menin, B.; Salati, S.; Adani, F. Organic wastes/by-products as alternative to CO2 for producing mixotrophic microalgae enhancing lipid production. Bioprocess Biosyst. Eng. 2020, 43, 1911-1919. [CrossRef]

35. Saxena, A.; Marella, T.K.; Singh, P.K.; Tiwari, A. Indoor mass cultivation of marine diatoms for biodiesel production using induction plasma synthesized nanosilica. Bioresour. Technol. 2021, 332, 125098. [CrossRef]

36. Roy, U.K.; Nielsen, B.V.; Milledge, J.J. Antioxidant Production in Dunaliella. Appl. Sci. 2021, 11, 3959. [CrossRef]

37. Figueroa-Torres, G.M.; Pittman, J.K.; Theodoropoulos, C. Optimisation of microalgal cultivation via nutrient-enhanced strategies: The biorefinery paradigm. Biotechnol. Biofuels 2021, 14. [CrossRef] [PubMed]

38. Patlakas, P.; Stathopoulos, C.; Flocas, H.; Kalogeri, C.; Kallos, G. Regional Climatic Features of the Arabian Peninsula. Atmosphere 2019, 10, 220. [CrossRef]

39. Mupambwa, H.A.; Hausiku, M.K.; Nciizah, A.D.; Dube, E. The unique Namib desert-coastal region and its opportunities for climate smart agriculture: A review. Cogent Food Agric. 2019, 5. [CrossRef]

40. Ghose, D.S. Pradhan, and Shabbiruddin, Development of model for assessment of renewable energy sources: A case study on Gujarat, India. Int. J. Ambient. Energy 2019. [CrossRef]

41. Mobin, S.M.; Chowdhury, H.; Alam, F. Commercially important bioproducts from microalgae and their current applications-A review. Energy Procedia 2019, 160, 752-760. [CrossRef]

42. Apandi, N.M.; Mohamed, R.M.S.R.; Al-Gheethi, A.; Kassim, A.H.M. Microalgal biomass production through phycoremediation of fresh market wastewater and potential applications as aquaculture feeds. Environ. Sci. Pollut.Res. 2019, 26, 3226-3242. [CrossRef]

43. Vandamme, D.; Foubert, I.; Muylaert, K. Flocculation as a low-cost method for harvesting microalgae for bulk biomass production. Trends Biotechnol. 2013, 31, 233-239. [CrossRef]

44. Garg, S.; Wang, L.G.; Schenk, P.M. Effective harvesting of low surface-hydrophobicity microalgae by froth flotation. Bioresour. Technol. 2014, 159, 437-441. [CrossRef]

45. Kebelmann, K.; Hornung, A.; Karsten, U.; Griffiths, G. Intermediate pyrolysis and product identification by TGA and Py-GC/MS of green microalgae and their extracted protein and lipid components. Biomass Bioenergy 2013, 49, 38-48. [CrossRef]

46. Yin, Z.; Chu, R.; Zhu, L.; Li, S.; Mo, F.; Hu, D.; Liu, C. Application of chitosan-based flocculants to harvest microalgal biomass for biofuel production: A review. Renew. Sustain. Energy Rev. 2021, 145, 111159. [CrossRef]

47. Lee, D.J.; Liao, G.Y.; Chang, Y.R.; Chang, J.S. Coagulation-membrane filtration of Chlorella vulgaris. Bioresour. Technol. 2012, 108, 184-189. [CrossRef] [PubMed]

48. Zheng, H.L.; Gao, Z.; Yin, J.; Tang, X.; Ji, X.; Huang, H. Harvesting of microalgae by flocculation with poly (gamma-glutamic acid). Bioresour. Technol. 2012, 112, 212-220. [CrossRef]

49. Ogbonna, C.N.; Nwoba, E.G. Bio-based flocculants for sustainable harvesting of microalgae for biofuel production. A review. Renew. Sustain. Energy Rev. 2021, 139, 110690. [CrossRef]

50. Ray, A.; Banerjee, S.; Das, D. Microalgal bio-flocculation: Present scenario and prospects for commercialization. Environ. Sci. Pollut. Res. 2021, 28, 26294-26312. [CrossRef] [PubMed]

51. Griffiths, G. Jasmonates: Biosynthesis, perception and signal transduction. Essays Biochem. 2020, 64, 501-512. [CrossRef]

52. Mohseni, F.; Zenooz, A.M. Flocculation of Chlorella vulgaris with alum and pH adjustment. Biotechnol. Appl. Biochem. 2021. [CrossRef] [PubMed]

53. Phasey, J.; Vandamme, D.; Fallowfield, H.J. Harvesting of algae in municipal wastewater treatment by calcium phosphate precipitation mediated by photosynthesis, sodium hydroxide and lime. Algal Res.-Biomass Biofuels Bioprod. 2017, 27, 115-120. [CrossRef] 
54. Xia, L.; Yinta, L.; Rong, H.; Shaoxian, S. Effective harvesting of microalgae by coagulation-flotation. R. Soc. Open Sci. 2017, 4, 170867. [CrossRef]

55. Almomani, F. Algal cells harvesting using cost-effective magnetic nano-particles. Sci. Total. Environ. 2020, 720, 12. [CrossRef] [PubMed]

56. Savvidou, M.G.; Dardavila, M.M.; Georgiopoulou, I.; Louli, V.; Stamatis, H.; Kekos, D.; Voutsas, E. Optimization of Microalga Chlorella vulgaris Magnetic Harvesting. Nanomaterials 2021, 11, 1614. [CrossRef]

57. Branyikova, I.; Prochazkova, G.; Potocar, T.; Jezkova, Z.; Branyik, T. Harvesting of Microalgae by Flocculation. Fermentation 2018, 4, 93. [CrossRef]

58. Van Dael, P. Role of n-3 long-chain polyunsaturated fatty acids in human nutrition and health: Review of recent studies and recommendations. Nutr. Res. Pract. 2021, 15, 137-159. [CrossRef]

59. Morabito, C.; Bournaud, C.; Maës, C.; Schuler, M.; Cigliano, A.R.; Dellero, Y.; Maréchal, E.; Amato, A.; Rébeillé, F. The lipid metabolism in thraustochytrids. Prog. Lipid Res. 2019, 76, 101007. [CrossRef]

60. Gohil, N.; Bhattacharjee, G.; Khambhati, K.; Braddick, D.; Singh, V. Engineering Strategies in Microorganisms for the Enhanced Production of Squalene: Advances, Challenges and Opportunities. Front. Bioeng. Biotechnol. 2019, 7, 50. [CrossRef]

61. Morrison, G.C.; Eftekhari, A.; Majluf, F.; Krechmer, J.E. Yields and Variability of Ozone Reaction Products from Human Skin. Environ. Sci. Technol. 2021, 55, 179-187. [CrossRef]

62. Santos, D.N.; Silva, F.S.; Verde, A.B.; Bittencourt, G.M.; Oliveira, A.L. Determination of functional compounds in blue shark (Prionace glauca) liver oil obtained by green technology. Grasas Y Aceites 2020, 71, 354. [CrossRef]

63. Mikrou, T.; Pantelidou, E.; Parasyri, N.; Papaioannou, A.; Kapsokefalou, M.; Gardeli, C.; Mallouchos, A. Varietal and Geographical Discrimination of Greek Monovarietal Extra Virgin Olive Oils Based on Squalene, Tocopherol, and Fatty Acid Composition. Molecules 2020, 25, 3818. [CrossRef] [PubMed]

64. Fernando, I.P.S.; Sanjeewa, K.K.A.; Samarakoon, K.W.; Lee, W.W.; Kim, H.S.; Jeon, Y.J. Squalene isolated from marine macroalgae Caulerpa racemosa and its potent antioxidant and anti-inflammatory activities. J. Food Biochem. 2018, 42, e12628. [CrossRef]

65. Bourdon, L.; Jensen, A.A.; Kavanagh, J.M.; McClure, D.D. Microalgal production of zeaxanthin. Algal Res.-Biomass Biofuels Bioprod. 2021, 55, 102266.

66. Rammuni, M.N.; Ariyadasa, T.U.; Nimarshana, P.H.V.; Attalage, R.A. Comparative assessment on the extraction of carotenoids from microalgal sources: Astaxanthin from H-pluvialis and beta-carotene from D. salina. Food Chem. 2019, 277, 128-134. [CrossRef] [PubMed]

67. Lim, K.C.; Yusoff, F.M.; Shariff, M.; Kamarudin, A.S. Dietary administration of astaxanthin improves feed utilization, growth performance and survival of Asian seabass, Lates calcarifer (Bloch, 1790). Aquac. Nutr. 2019, 25, 1410-1421. [CrossRef]

68. Gargouch, N.; Karkouch, I.; Elleuch, J.; Elkahoui, S.; Michaud, P.; Abdelkafi, S.; Laroche, C.; Fendri, I. Enhanced B-phycoerythrin production by the red microalga Porphyridium marinum: A powerful agent in industrial applications. Int. J. Biol. Macromol. 2018, 120, 2106-2114. [CrossRef]

69. García, A.B.; Longo, E.; Murillo, M.C.; Bermejo, R. Using a B-Phycoerythrin Extract as a Natural Colorant: Application in Milk-Based Products. Molecules 2021, 26, 297. [CrossRef]

70. Sui, S.F. Structure of Phycobilisomes. Annu. Rev. Biophys. 2021, 50, 53-72. [CrossRef]

71. Dong, Y.; Wei, Z.H.; Xue, C.H. Recent advances in carrageenan-based delivery systems for bioactive ingredients: A review. Trends Food Sci. Technol. 2021, 112, 348-361. [CrossRef]

72. Liu, J.; Yang, S.; Li, X.; Yan, Q.; Reaney, M.J.; Jiang, Z. Alginate Oligosaccharides: Production, Biological Activities, and Potential Applications. Compr. Rev. Food Sci. Food Saf. 2019, 18, 1859-1881. [CrossRef]

73. Ismail, M.M.; Alotaibi, B.S.; El-Sheekh, M.M. Therapeutic Uses of Red Macroalgae. Molecules 2020, 25, 4411. [CrossRef]

74. Shrestha, S.; Zhang, W.; Smid, S.D. Phlorotannins: A review on biosynthesis, chemistry and bioactivity. Food Biosci. 2021, 39, 100832. [CrossRef]

75. Milledge, J.J.; Nielsen, B.V.; Harvey, P.J. The inhibition of anaerobic digestion by model phenolic compounds representative of those from Sargassum muticum. J. Appl. Phycol. 2019, 31, 779-786. [CrossRef]

76. Pradyawong, S.; Juneja, A.; Sadiq, M.B.; Noomhorm, A.; Singh, V. Comparison of Cassava Starch with Corn as a Feedstock for Bioethanol Production. Energies 2018, 11, 3476. [CrossRef]

77. Ran, W.; Wang, H.; Liu, Y.; Qi, M.; Xiang, Q.; Yao, C.; Zhang, Y.; Lan, X. Storage of starch and lipids in microalgae: Biosynthesis and manipulation by nutrients. Bioresour. Technol. 2019, 291, 121894. [CrossRef]

78. Kumar, S.; Gupta, R.; Kumar, G.; Sahoo, D.; Kuhad, R.C. Bioethanol production from Gracilaria verrucosa, a red alga, in a biorefinery approach. Bioresour. Technol. 2013, 135, 150-156. [CrossRef] [PubMed]

79. Dagle, V.L.; Lopez, J.S.; Cooper, A.; Luecke, J.; Swita, M.; Dagle, R.A.; Gaspar, D. Production and fuel properties of iso-olefins with controlled molecular structure and obtained from butene oligomerization. Fuel 2020, 277, 118147. [CrossRef]

80. O'Neil, G.W.; Culler, A.R.; Williams, J.R.; Burlow, N.P. Production of Jet Fuel Range Hydrocarbons as a Coproduct of Algal Biodiesel by Butenolysis of Long-Chain Alkenones. Energy Fuels 2015, 29, 922-930. [CrossRef]

81. Hu, Y.; Wang, S.; Wang, Q.; He, Z.; Abomohra, A.E.F.; Cao, B. Influence of torrefaction pretreatment on the pyrolysis characteristics of seaweed biomass. Cellulose 2019, 26, 8475-8487. [CrossRef]

82. Allen, E.; Wall, D.M.; Herrmann, C.; Xia, A.; Murphy, J.D. What is the gross energy yield of third generation gaseous biofuel sourced from seaweed? Energy 2015, 81, 352-360. [CrossRef] 
83. Chynoweth, D.P.; Owens, J.M.; Legrand, R. Renewable methane from anaerobic digestion of biomass. Renew. Energy 2001, 22, 1-8. [CrossRef]

84. Mhatre, A.; Gore, S.; Mhatre, A.; Trivedi, N.; Sharma, M.; Pandit, R.; Anil, A.; Lali, A. Effect of multiple product extractions on bio-methane potential of marine macrophytic green alga Ulva lactuca. Renew. Energy 2019, 132, 742-751. [CrossRef]

85. Murphy, F.; Devlin, G.; Deverell, R.; McDonnell, K. Biofuel Production in Ireland-An Approach to 2020 Targets with a Focus on Algal Biomass. Energies 2013, 6, 6391-6412. [CrossRef]

86. Rajendran, K.; Browne, J.D.; Murphy, J.D. What is the level of incentivisation required for biomethane upgrading technologies with carbon capture and reuse? Renew. Energy 2019, 133, 951-963. [CrossRef]

87. Gao, G.; Burgess, J.; Wu, M.; Wang, S.; Gao, K. Using macroalgae as biofuel: Current opportunities and challenges. Bot. Mar. 2020, 63, 355-370. [CrossRef]

88. Roberts, K.P.; Heaven, S.; Banks, C.J. Comparative testing of energy yields from micro-algal biomass cultures processed via anaerobic digestion. Renew. Energy 2016, 87, 744-753. [CrossRef]

89. Klassen, V.; Blifernez-Klassen, O.; Bax, J.; Kruse, O. Wastewater-borne microalga Chlamydomonas sp.: A robust chassis for efficient biomass and biomethane production applying low-N cultivation strategy. Bioresour. Technol. 2020, 315, 123825. [CrossRef]

90. Patel, S.K.S.; Kumar, P.; Mehariya, S.; Purohit, H.J.; Lee, J.; Vipin, C.; Kalia, V.C. Enhancement in hydrogen production by co-cultures of Bacillus and Enterobacter. Int. J. Hydrogen Energy 2014, 39, 14663-14668. [CrossRef]

91. Oey, M.; Sawyer, A.L.; Ross, I.L.; Hankamer, B. Challenges and opportunities for hydrogen production from microalgae. Plant Biotechnol. J. 2016, 14, 1487-1499. [CrossRef]

92. Medisetty, V.M.; Kumar, R.; Ahmadi, M.H.; Vo, D.V.N.; Ochoa, A.A.V.; Solanki, R. Overview on the Current Status of Hydrogen Energy Research and Development in India. Chem. Eng. Technol. 2020, 43, 613-624. [CrossRef]

93. Chai, S.; Zhang, G.; Li, G.; Zhang, Y. Industrial hydrogen production technology and development status in China: A review. Clean Technol. Environ. Policy 2021, 23, 1931-1946. [CrossRef]

94. Goswami, R.K.; Mehariya, S.; Obulisamy, P.K.; Verma, P. Advanced microalgae-based renewable biohydrogen production systems: A review. Bioresour. Technol. 2021, 320, 124301. [CrossRef] [PubMed]

95. Wang, J.; Yu, L.J.; Wang, W.; Yan, Q.; Kuang, T.; Qin, X.; Shen, J.R. Structure of plant photosystem I-light harvesting complex I supercomplex at 2.4 angstrom resolution. J. Integr. Plant Biol. 2021. [CrossRef] [PubMed]

96. Stirbet, A.; Lazár, D.; Guo, Y.; Govindjee, G. Photosynthesis: Basics, history and modelling. Ann. Bot. 2020, 126, 511-537. [CrossRef]

97. Khetkorn, W.; Rastogi, R.P.; Incharoensakdi, A.; Lindblad, P.; Madamwar, D.; Pandey, A.; Larroche, C. Microalgal hydrogen production - A review. Bioresour. Technol. 2017, 243, 1194-1206. [CrossRef] [PubMed]

98. Picone, N.; Mohammadi, S.S.; Waajen, A.C.; Alen, V.T.A.; Jetten, M.S.M.; Pol, A.; Op-den Camp, H.J.M. More Than a Methanotroph: A Broader Substrate Spectrum for Methylacidiphilum fumariolicum SolV. Front. Microbiol. 2020, 11, 11. [CrossRef]

99. Wang, G.Y.; Dai, Y.; Yang, H.; Xiong, Q.; Wang, K.; Zhou, J.; Li, Y.; Wang, S. A Review of Recent Advances in Biomass Pyrolysis. Energy Fuels 2020, 34, 15557-15578. [CrossRef]

100. Lee, X.J.; Onga, H.C.; Gan, Y.Y.; Chen, W.H.; Meurah, T.; Mahlia, I. State of art review on conventional and advanced pyrolysis of macroalgae and microalgae for biochar, bio-oil and bio-syngas production. Energy Convers. Manag. 2020, 210, 112707. [CrossRef]

101. Gong, X.; Zhang, B.; Zhang, Y.; Huang, Y.; Xu, M. Investigation on Pyrolysis of Low Lipid Microalgae Chlorella vulgaris and Dunaliella salina. Energy Fuels 2014, 28, 95-103. [CrossRef]

102. Miao, X.L.; Wu, Q.Y.; Yang, C.Y. Fast pyrolysis of microalgae to produce renewable fuels. J. Anal. Appl. Pyrolysis 2004, 71, 855-863. [CrossRef]

103. Gollakota, A.R.K.; Kishore, N.; Gu, S. A review on hydrothermal liquefaction of biomass. Renew. Sustain. Energy Rev. 2018, 81, 1378-1392. [CrossRef]

104. Djandja, O.S.; Wang, Z.; Chen, L.; Qin, L.; Wang, F.; Xu, Y.; Peigao Duan, P. Progress in Hydrothermal Liquefaction of Algal Biomass and Hydrothermal Upgrading of the Subsequent Crude Bio-Oil: A Mini Review. Energy Fuels 2020, 34, 11723-11751. [CrossRef]

105. Zheng, Y.; Jida Wang, J.; Li, D.; Liu, C.; Lu, Y.; Lin, X.; Zheng, Z. Activity and selectivity of Ni-Cu bimetallic zeolites catalysts on biomass conversion for bio-aromatic and bio-phenols. J. Energy Inst. 2021, 97, 58-72. [CrossRef]

106. Jena, U.; Das, K.C. Comparative Evaluation of Thermochemical Liquefaction and Pyrolysis for Bio-Oil Production from Microalgae. Energy Fuels 2011, 25, 5472-5482. [CrossRef]

107. Castello, D.; Pedersen, T.H.; Rosendahl, L.A. Continuous Hydrothermal Liquefaction of Biomass: A Critical Review. Energies 2018, 11, 3165. [CrossRef]

108. Gu, X.; Martinez-Fernandez, J.S.; Pang, N.; Fu, X.; Chen, S. Recent development of hydrothermal liquefaction for algal biorefinery. Renew. Sustain. Energy Rev. 2020, 121, 10970-10977. [CrossRef]

109. Latif, N.; Ong, M.Y.; Nomanbhay, S. Hydrothermal liquefaction of Malaysia's algal biomass for high-quality bio-oil production. Eng. Life Sci. 2019, 19, 246-269. [CrossRef]

110. Raikova, S.; Allen, M.J.; Chuck, C.J. Hydrothermal liquefaction of macroalgae for the production of renewable biofuels. Biofuels Bioprod. Biorefin. 2019, 13, 1483-1504. [CrossRef]

111. Ishika, T.; Moheimani, N.R.; Bahri, P.A. Sustainable saline microalgae co-cultivation for biofuel production: A critical review. Renew. Sustain. Energy Rev. 2017, 78, 356-368. [CrossRef] 
112. Li-Beisson, Y.; Beisson, F.; Riekhof, W. Metabolism of acyl-lipids in Chlamydomonas reinhardtii. Plant J. 2015, 82, 504-522. [CrossRef] [PubMed]

113. Ortiz, R.; Geleta, M.; Gustafsson, C.; Lager, I.; Hofvander, P.; Löfstedt, C.; Cahoon, E.B.; Minina, E.; Bozhkov, P.; Stymne, S. Oil crops for the future. Curr. Opin. Plant Biol. 2020, 56, 181-189. [CrossRef]

114. Griffiths, G.; Morse, N. Clinical Applications of C-18 and C-20 Chain Length Polyunsaturated Fatty Acids and Their Biotechnological Production in Plants. J. Am. Oil Chem. Soc. 2006, 73, 171-185. [CrossRef]

115. Suganya, T.; Varman, M.; Masjuki, H.H.; Renganathan, S. Macroalgae and microalgae as a potential source for commercial applications along with biofuels production: A biorefinery approach. Renew. Sustain. Energy Rev. 2016, 55, 909-941. [CrossRef]

116. El-Sheekh, M.M.; Hamouda, R.A. Lipids extraction from the green alga Ankistrodesmus falcatus using different methods. Rend. Lincei-Sci. Fis. E Nat. 2016, 27, 589-595. [CrossRef]

117. Chen, J.; Li, J.; Dong, W.; Zhang, X.; Tyagi, R.D.; Drogui, P.; Surampalli, R.Y. The potential of microalgae in biodiesel production. Renew. Sustain. Energy Rev. 2018, 90, 336-346. [CrossRef]

118. Kruger, J.S.; Knoshaug, E.P.; Dong, T.; Hull, T.C.; Pienkos, P.T. Catalytic Hydroprocessing of Single-Cell Oils to Hydrocarbon Fuels Converting microbial lipids to fuels is a promising approach to replace fossil fuels. Johns. Matthey Technol. Rev. 2021, 65, 227-246. [CrossRef]

119. Zheng, Y.; Dillon, J.T.; Zhang, Y.; Huang, Y. Discovery of Alkenones with Variable Methylene-Interrupted Double Bonds: Implications for the Biosynthetic Pathway. J. Phycol. 2016, 52, 1037-1050. [CrossRef]

120. Cañavate, J.; Hachero-Cruzado, I.; Pérez-Gavilán, C.; Fernández-Díaz, C. Lipid dynamics and nutritional value of the estuarine strainIsochrysis galbanaVLP grown from hypo to hyper salinity. J. Appl. Phycol. 2020, 32, 3749-3766. [CrossRef]

121. Al-Lwayzy, S.H.; Yusaf, T. Chlorella protothecoides Microalgae as an Alternative Fuel for Tractor Diesel Engines. Energies 2013, 6, 766-783. [CrossRef]

122. Karmakar, R.; Kundu, K.; Rajor, A. Fuel properties and emission characteristics of biodiesel produced from unused algae grown in India. Pet. Sci. 2018, 15, 385-395. [CrossRef]

123. Jacob, A.; Ashok, B.; Alagumalai, A.; Chyuan, O.H.; Le, P.T.K. Critical review on third generation micro algae biodiesel production and its feasibility as future bioenergy for IC engine applications. Energy Convers. Manag. 2021, 228, 113655. [CrossRef]

124. Sharma, V.; Duraisamy, G. Production and characterization of bio-mix fuel produced from the mixture of raw oil feedstock, and its effects on performance and emission analysis in DICI diesel engine. Environ. Sci. Pollut. Res. 2019, 26, 16742-16761. [CrossRef] [PubMed]

125. Karthikeyan, S.; Kalaimurugan, K.; Prathima, A. Quality analysis studies on biodiesel production of neochloris oleoabundans algae. Energy Sour. Part A Recovery Util. Environ. Eff. 2018, 40, 439-445. [CrossRef]

126. Subramaniam, M.; Solomon, J.M.; Nadanakumar, V.; Anaimuthu, S.; Sathyamurthy, R. Experimental investigation on performance, combustion and emission characteristics of DI diesel engine using algae as a biodiesel. Energy Rep. 2020, 6, 1382-1392. [CrossRef]

127. Rajak, U.; Nashine, P.; Verma, T.N. Effect of spirulina microalgae biodiesel enriched with diesel fuel on performance and emission characteristics of CI engine. Fuel 2020, 268, 117305. [CrossRef]

128. Rajak, U.; Nashine, P.; Verma, T.N.; Pugazhendhi, A. Performance and emission analysis of a diesel engine using hydrogen enriched n-butanol, diethyl ester and Spirulina microalgae biodiesel. Fuel 2020, 271, 117645. [CrossRef]

129. Karthikeyan, S.; Prathima, A. Environmental effect of CI engine using microalgae methyl ester with doped nano additives. Transp. Res. Part D Transp. Environ. 2017, 50, 385-396. [CrossRef]

130. Al-Lwayzy, S.H.; Yusaf, T. Diesel engine performance and exhaust gas emissions using Microalgae Chlorella protothecoides biodiesel. Renew. Energy 2017, 101, 690-701. [CrossRef]

131. Mathimani, T.; Kumar, T.S.; Chandrasekar, M.; Uma, L.; Prabaharan, D. Assessment of fuel properties, engine performance and emission characteristics of outdoor grown marine Chlorella vulgaris BDUG 91771 biodiesel. Renew. Energy 2017, 105, 637-646. [CrossRef]

132. Hossain, F.M.; Nabi, M.N.; Brown, R.J. Investigation of diesel engine performance and exhaust emissions of microalgae fuel components in a turbocharged diesel engine. Energy Convers. Manag. 2019, 186, 220-228. [CrossRef]

133. Tseng, Y.H.; Lee, T.I.; Doane, A.J.; Butterfield, A.E.; McLennan, J.D.; Mohanty, A.K.; Pease, L.F. Periodic symmetry defined bioreactors enhance algae growth. Environ. Sci. Water Res. Technol. 2019, 5, 1037-1045. [CrossRef]

134. Yan, Q.; Pfleger, B.F. Revisiting metabolic engineering strategies for microbial synthesis of oleochemicals. Metab. Eng. 2020, 58, 35-46. [CrossRef]

135. Koyande, A.K.; Show, P.L.; Guo, R.; Tang, B.; Ogino, C.; Chang, J.S. Bio-processing of algal bio-refinery: A review on current advances and future perspectives. Bioengineered 2019, 10, 574-592. [CrossRef]

136. Dong, T.; Knoshaug, E.P.; Davis, R.; Laurens, L.M.L.; Wychen, S.V.; Philip, T.; Pienkos, P.T.; Nagle, N. Combined algal processing: A novel integrated biorefinery process to produce algal biofuels and bioproducts. Algal Res.-Biomass Biofuels Bioprod. 2016, 19, 316-323. [CrossRef] 